Article

\title{
Evaluation of Pseudopteroxazole and Pseudopterosin Derivatives against Mycobacterium tuberculosis and Other Pathogens
}

\author{
Malcolm W. B. McCulloch ${ }^{1}$, Brad Haltli ${ }^{1,2}$, Douglas H. Marchbank ${ }^{1}$ and Russell G. Kerr ${ }^{1,2, *}$ \\ 1 Department of Chemistry and Department of Biomedical Sciences, Atlantic Veterinary College, \\ University of Prince Edward Island, Charlottetown, PEI C1A 4P3, Canada; \\ E-Mails: mmcculloch@upei.ca (M.W.B.M.); bhaltli@upei.ca (B.H.); dmarchbank@upei.ca (D.H.M.) \\ 2 Nautilus Biosciences Canada, Inc., Charlottetown, PEI C1A 4P3, Canada \\ * Author to whom correspondence should be addressed; E-Mail: rkerr@upei.ca; \\ Tel.: +1-902-566-0565; Fax: +1-902-566-7445.
}

Received: 12 June 2012; in revised form: 25 July 2012 / Accepted: 1 August 2012 /

Published: 15 August 2012

\begin{abstract}
Pseudopterosins and pseudopteroxazole are intriguing marine natural products that possess notable antimicrobial activity with a commensurate lack of cytotoxicity. New semi-synthetic pseudopteroxazoles, pseudopteroquinoxalines and pseudopterosin congeners along with simple synthetic mimics of the terpene skeleton were synthesized. In order to build structure-activity relationships, a set of 29 new and previously reported compounds was assessed for in vitro antimicrobial and cytotoxic activities. A number of congeners exhibited antimicrobial activity against a range of Gram-positive bacteria including Mycobacterium tuberculosis $\mathrm{H}_{37} \mathrm{Rv}$, with four displaying notable antitubercular activity against both replicating and non-replicating persistent forms of $M$. tuberculosis. One new semi-synthetic compound, 21-((1H-imidazol-5-yl)methyl)-pseudopteroxazole (7a), was more potent than the natural products pseudopterosin and pseudopteroxazole and exhibited equipotent activity against both replicating and non-replicating persistent forms of M. tuberculosis with a near absence of in vitro cytotoxicity. Pseudopteroxazole also exhibited activity against strains of $M$. tuberculosis $\mathrm{H}_{37} \mathrm{Rv}$ resistant to six clinically used antibiotics.
\end{abstract}

Keywords: pseudopteroxazoles; semi-synthesis; Mycobacterium tuberculosis; antibiotic-resistance 


\section{Introduction}

Mycobacterium tuberculosis is the causative agent of tuberculosis (TB), a disease which remains a serious threat to the global human population, causing nearly 2 million deaths and over 9 million new infections annually [1]. While the majority of TB patients can be cured using existing antibiotic treatment regimens, several challenges still exist for the treatment of TB. A key drawback to current therapies is the lengthy duration (6-9 months) required to ensure complete eradication of the disease. The long duration and associated toxicity result in poor patient compliance which contributes to the spread of TB and selects for drug-resistant forms of the disease. The need for extended TB treatment regimens is in large part due to the resistance of non-replicating persistent (NRP) subpopulations of M. tuberculosis to antibiotic treatment. The treatment of TB is further complicated by the increasing occurrence of strains resistant to multiple drugs, which account for approximately 5\% of TB cases [2]. To improve the outcome of existing TB treatments, new classes of molecules active against NRP-TB and emerging drug-resistant strains are greatly needed $[3,4]$. Natural products represent an obvious starting point to meet this desideratum given that they have historically provided a wealth of antibiotic lead compounds which have been successfully developed into efficacious drugs [5].

The diterpenes pseudopteroxazole (1) and homopseudopteroxazole (2) (Figure 1) are trace marine natural products from Pseudopterogorgia elisabethae with reported activity against Mycobacterium tuberculosis $\mathrm{H}_{37} \mathrm{Rv}$ [6,7]. Despite interest in 1 by the synthetic chemistry community [8-10], no medicinal chemistry efforts around this scaffold were reported until our recent semi-synthesis of 1, 2 and 14 congeners from relatively abundant natural pseudopterosins $G-J$ (3a-3d) [11]. In this earlier report we described activity against model mycobacteria (M. smegmatis and M. diernhoferi) and clinically relevant Gram-positive bacteria: methicillin-resistant Staphylococcus aureus (MRSA) and vancomycin-resistant Enterococcus faecium (VRE). The pseudopteroxazole pharmacophore is not known, thus an aim of the current study was to conduct a preliminary examination of structure-activity relationships (SAR), especially against M. tuberculosis $\mathrm{H}_{37} \mathrm{Rv}$.

Figure 1. Structures of pseudopteroxazole (1), homopseudopteroxazole (2) and pseudopterosins G-J (3a-d).
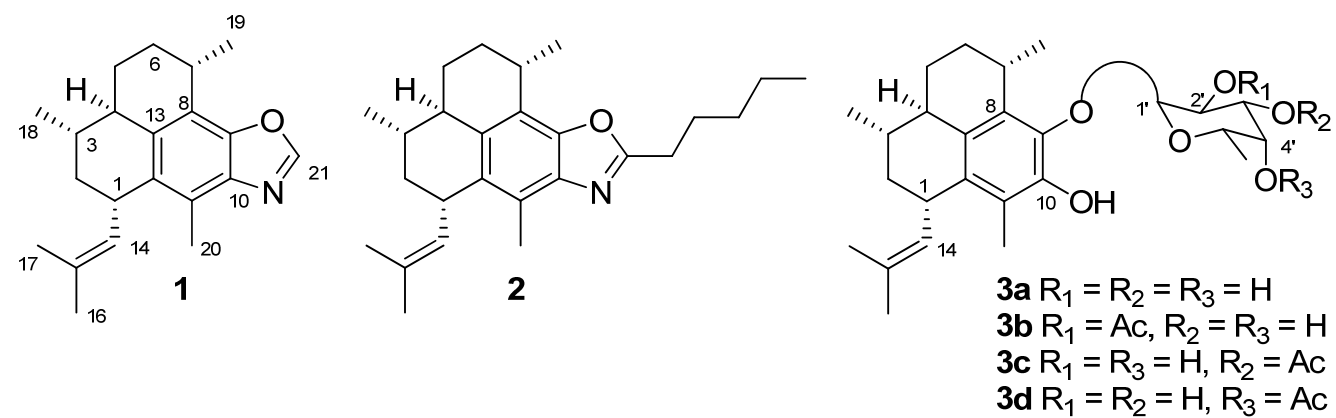

In the previous report we examined the effect of modifying the oxazole moiety in $\mathbf{1}$ by synthesizing C-21 substituted derivatives of $\mathbf{1}$ and also by preparing isopseudopteroxazoles, which are pseudopteroxazole congeners where the location of the oxazole nitrogen and oxygen atoms are inverted. We found that appending lipophilic moieties to the C-21 oxazole decreased the antimicrobial activity against model mycobacteria, MRSA and VRE, whereas isopseudopteroxazoles and their 
corresponding pseudopteroxazoles exhibited similar antimicrobial activity [11]. We report herein the in vitro activity of the aforementioned pseudopteroxazole compound set and new structurally related compounds against $M$. tuberculosis $\mathrm{H}_{37} \mathrm{Rv}$ and a model of NRP-TB. Given that the pseudopterosins $[12,13]$ are also known to possess antibiotic activity against various Gram-positive bacteria [14-17] including M. tuberculosis [15], we aimed to synthesize and evaluate derivatives based on the parent aglycone scaffold of both pseudopterosins G-J and pseudopteroxazole. In this regard we have: (1) substituted the oxazole moiety in 1 with a pyrazine to generate pseudopteroquinoxaline (5); (2) synthesized a range of pseudopteroxazole derivatives such as 21-((1H-imidazol-5-yl)methyl)-pseudopteroxazole (7a) and the regioisomer (7b), which are pseudopteroxazoles with polar, amphoteric imidazole side chains that possess activity in a NRP-TB model; (3) examined the biological effect of altering the phenolic substituents on the pseudopterosins G-J aglycone (4); and (4) synthesized small prenylated phenol derivatives and related glycosides as mimics of the pseudopterosin/pseudopteroxazole structural core.

\section{Results and Discussion}

\subsection{Chemistry}

Pseudopteroxazoles $(\mathbf{1}, \mathbf{2}, \mathbf{2 2}-\mathbf{3 3})$ were synthesized as previously described [11]. The synthesis of the novel compounds is discussed below.

\subsubsection{Synthesis of Pseudopteroquinoxalines 5 and $\mathbf{6}$}

Pseudopteroquinoxaline (5) was synthesized in one-pot by oxidation of the pseudopterosin G-J aglycone (4) [18] with $\mathrm{Ag}_{2} \mathrm{O}$ and condensation with ethylenediamine (Scheme 1). In an alternative synthesis, treatment of $\mathbf{4}$ with Dess-Martin periodinane in $\mathrm{DCM} / \mathrm{MeOH}$, followed by reaction with ethylenediamine yielded $\mathbf{5}$ and the tertiary ether $\mathbf{6}$ as a minor side product.

Scheme 1. Reagents and conditions: (a) $\mathrm{Ag}_{2} \mathrm{O}$ (1.5 equiv.), $\mathrm{NH}_{2}\left(\mathrm{CH}_{2}\right)_{2} \mathrm{NH}_{2}, \Delta, \mathrm{EtOH}$, for 5. (b) (i) Dess-Martin periodinane (2 equiv.), $\mathrm{NH}_{2}\left(\mathrm{CH}_{2}\right)_{2} \mathrm{NH}_{2}, \mathrm{DCM} / \mathrm{H}_{2} \mathrm{O} / \mathrm{MeOH}$ r.t.; (ii) $\Delta$, isopropyl alcohol, for $\mathbf{5}$ and $\mathbf{6}$.

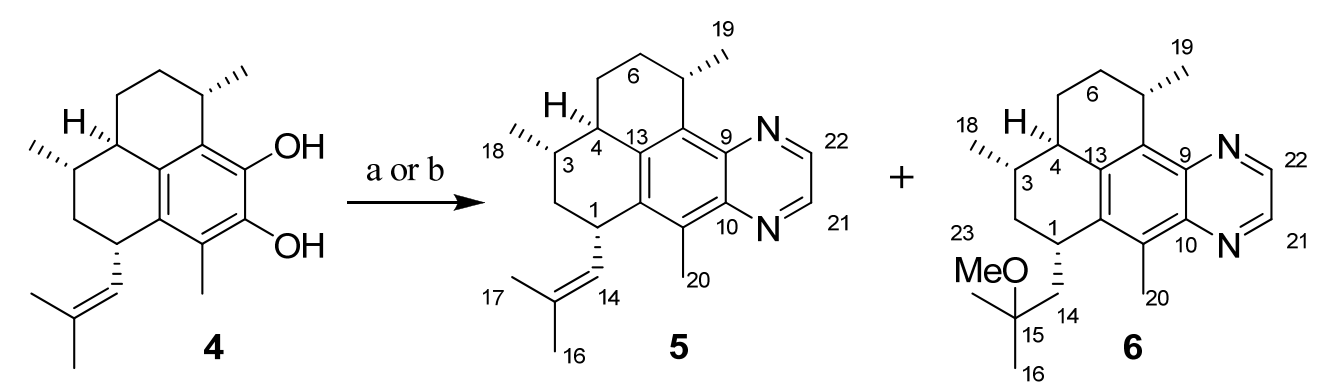

\subsubsection{Synthesis of Pseudopteroxazoles $7 \mathbf{a}$ and $7 \mathbf{b}$}

Synthesis of the novel derivatives 21-((1H-imidazol-5-yl)methyl)-pseudopteroxazole (7a) and the regioisomer (7b) followed the previously reported general method utilizing the aglycone (4), $\mathrm{Ag}_{2} \mathrm{O}$ and histidine (Scheme 2). After purification by flash chromatography, a mixture of $\mathbf{7 a}$ and $\mathbf{7 b}$ was obtained in a 2.4:1 ratio as determined by ${ }^{1} \mathrm{H}$ NMR analysis. This product regioisomer ratio differs from the 
$\sim 10$ :1 ratio previously observed with other amino acids [11]. While the reasons behind this are under further investigation, it is conceivable that the nucleophilic imidazole attacks the ortho-quinone at C-10, which increases the relative rate of condensation at C-9. Separation of the regioisomers $(\mathbf{7 a} / \mathbf{7} \mathbf{b})$ proved challenging; while HPLC did not lead to peak resolution, a portion of the material was slightly enriched in $\mathbf{7 a}$ (3:1 ratio) by peak shaving. This material (7a/7b) has been thoroughly and unambiguously characterized; spectra and analytical chromatograms are provided in the supporting information.

Scheme 2. Reagents and conditions: (a) $\mathrm{Ag}_{2} \mathrm{CO}_{3}$ (1.4 equiv.), $\Delta, \mathrm{MeOH} / \mathrm{H}_{2} \mathrm{O}$ (10:1);

(b) histidine (6.7 equiv. in batches), $\Delta$; (c) $\mathrm{HCO}_{2} \mathrm{H}$ (HPLC purification).<smiles></smiles>

\subsubsection{Synthesis of Pseudopterosin Derivatives 8-12}

The mono-pentyl ether (8) derivative of the pseudopterosin G-J aglycone (4) was synthesized to provide a phenolic mimic of homopseudopteroxazole (2), given that $\mathbf{2}$ possesses a pentyl chain and was reportedly active against $M$. tuberculosis $\mathrm{H}_{37} \mathrm{Rv}$ [7]. The mono-pentyl ether (8) and mono-methyl ether (9) [19] were synthesized by alkylation of 3a-d with iodopentane or iodomethane, respectively, followed by acid catalyzed hydrolysis of the fucose moiety (Scheme 3 ). Further substitution of the free phenol in 9 by treatment with the appropriate electrophile yielded the di-methyl ether (10), the triflate (11) and the carbamate (12).

Scheme 3. Reagents and conditions: (a) $\mathrm{K}_{2} \mathrm{CO}_{3}$, iodopentane, $\Delta$, acetone; (b) $\mathrm{HCl}$, $\Delta$, $\mathrm{MeOH}$; (c) $\mathrm{K}_{2} \mathrm{CO}_{3}$, MeI, $\Delta$ acetone; (d) $\mathrm{HCl}, \Delta$, MeOH; (e) For 10, NaH, MeI, THF; (f) For 11, Hunig's base, $\mathrm{Tf}_{2} \mathrm{O}, \mathrm{DCM}, 0{ }^{\circ} \mathrm{C} \rightarrow$ r.t.; (g) For 12, NaH, $\left(\mathrm{CH}_{3}\right)_{2} \mathrm{NCOCl}$, THF.

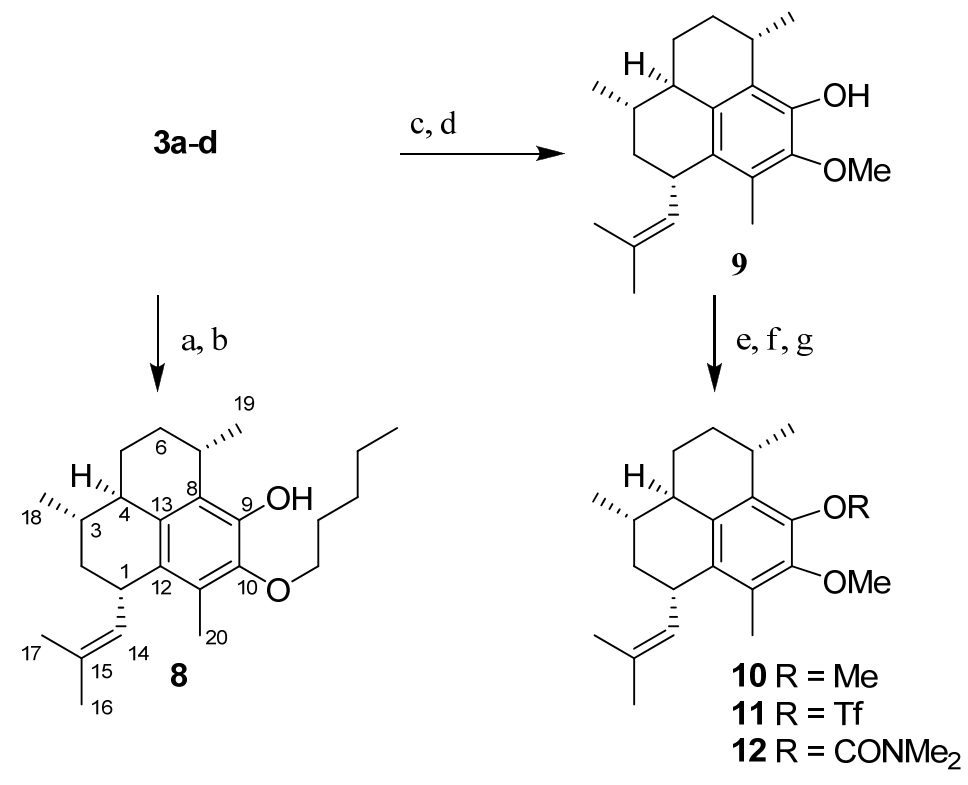




\subsubsection{Synthesis of Pseudopterosin Mimics 14-20}

The syntheses of the prenylated aromatic mimics of pseudopterosin are shown in Scheme 4. Acid catalyzed reaction of 2,6-dimethoxyphenol (13) with 2-methyl-3-buten-2-ol yielded the mono-, di- and tri-prenylated derivatives $(14,15 \& 16)$. Compound 13 was further utilized as a model compound to develop conditions suitable for the glycosylation of these phenols. Treatment of $\mathbf{1 3}$ with the benzoylated glycosyl donor 21 and $\mathrm{BF}_{3} \cdot \mathrm{Et}_{2} \mathrm{O}$ yielded 17, which was deprotected with $\mathrm{K}_{2} \mathrm{CO}_{3}$ to give the galactoside 18 in high yield. Identical reaction sequences utilizing 14 gave the benzoylated glycoside 19 followed by the desired prenylated galactoside 20. Attempts to glycosylate $\mathbf{1 5}$ were unsuccessful.

Scheme 4. Reagents and conditions: (a) 2-methyl-3-buten-2-ol (1.9 equiv.), TsOH (cat.), $\mathrm{DCM} / \mathrm{MeOH}, \Delta$; (b) 21, $\mathrm{BF}_{3} \cdot \mathrm{Et}_{2} \mathrm{O},-78^{\circ} \mathrm{C}, \mathrm{DCM}$; (c) $\mathrm{K}_{2} \mathrm{CO}_{3}, \mathrm{MeOH}: \mathrm{MTBE}(5: 1)$.
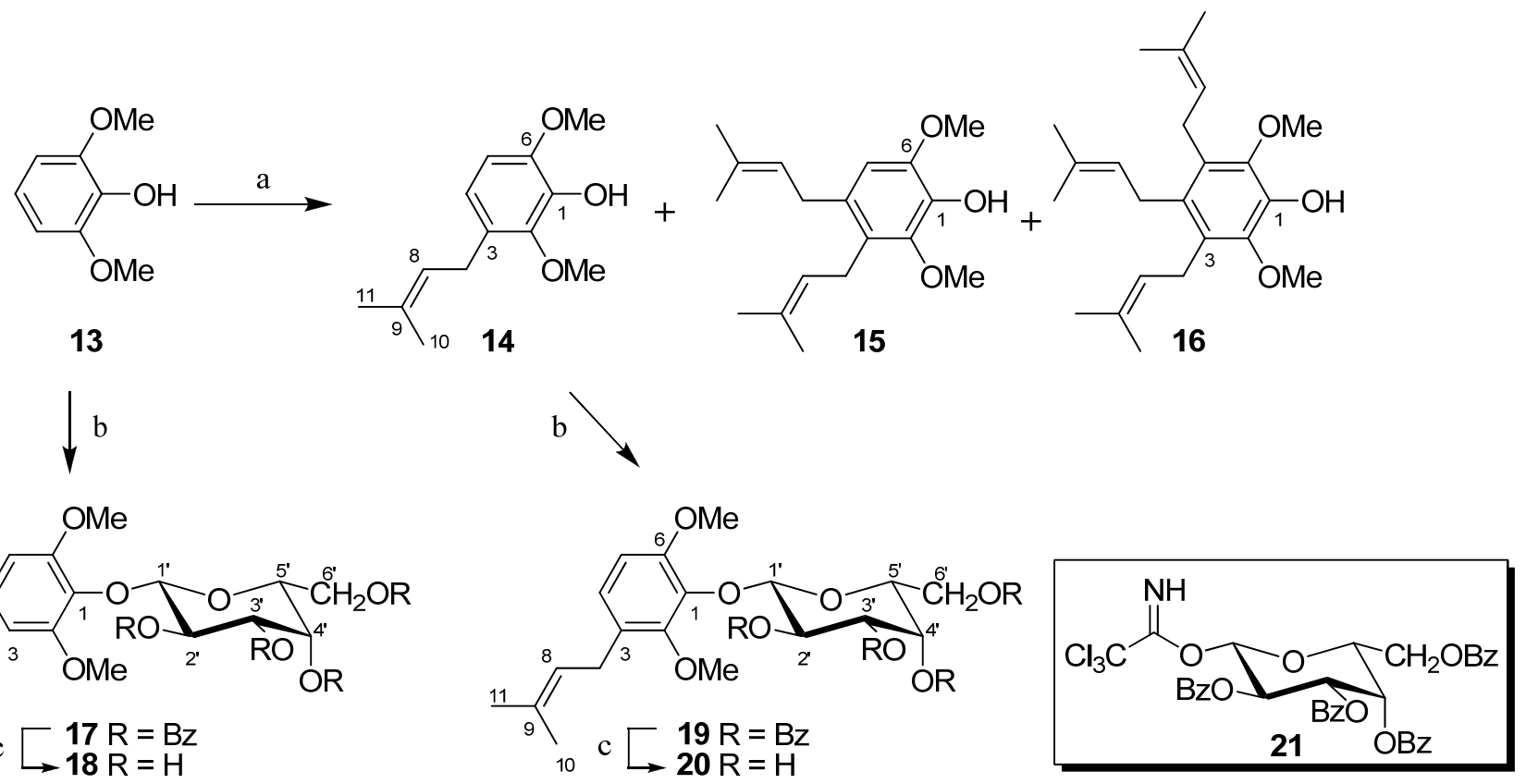

\subsection{Antibacterial Activity}

\subsubsection{Activity of Semi-Synthetic Pseudopteroxazoles in M. tuberculosis Assays}

The biological activities of fifteen semi-synthetic pseudopteroxazoles and isopseudopteroxazoles are shown in Table 1 . The minimum inhibitory concentrations (MICs) against M. tuberculosis $\mathrm{H}_{37} \mathrm{Rv}$ (ATCC 27294) were determined in vitro using the microplate Alamar blue assay (MABA) [20]. Generally substitutions at the C-21 oxazole moiety in $\mathbf{1}$ lead to congeners with reduced activity against $M$. tuberculosis $\mathrm{H}_{37} \mathrm{Rv}$, however, three compounds (7a/7b, 22 \& 25) showed activity against $M$. tuberculosis $\mathrm{H}_{37} \mathrm{Rv}$ comparable to 1. Semi-synthetic homopseudopteroxazole (2) was not active against M. tuberculosis $\mathrm{H}_{37} \mathrm{Rv}$ in contrast to the literature report for natural 2 isolated from $P$. elisabethae, which was reported to show $80 \%$ inhibition against M. tuberculosis $\mathrm{H}_{37} \mathrm{Rv}$ at $12.5 \mu \mathrm{g} / \mathrm{mL}$ $(40 \mu \mathrm{M})$ [7]. Our result with 2 was consistent with the inactivity of other members of the series with lipophilic C-21 substituents. 
Table 1. Antitubercular, low-oxygen-recovery assay (LORA) and cytotoxic activity of semi-synthetic pseudopteroxazoles in vitro.

\begin{tabular}{|c|c|c|c|c|c|}
\hline Compound & $\begin{array}{c}\text { MABA }^{\text {a }} \text { MIC } \\
{[\mu \mathrm{g} / \mathrm{mL}](\% \text { inh })}\end{array}$ & $\begin{array}{l}\text { LORA }^{b} \\
\%^{\text {inh }}{ }^{c}\end{array}$ & $\begin{array}{c}\text { LORA }^{b} \text { MIC } \\
{[\mu \mathrm{g} / \mathrm{mL}]}\end{array}$ & $\begin{array}{c}\text { Vero cell } \mathrm{IC}_{50} \\
{[\mu \mathrm{g} / \mathrm{mL}](\% \text { inh })}\end{array}$ & SI $^{d}$ \\
\hline $1(\mathrm{Ptx}-\mathrm{H})$ & 15 & 99.7 & 50 & $>128(0 \%)$ & $>8.6$ \\
\hline $2\left(\operatorname{Ptx}-\left(\mathrm{CH}_{2}\right)_{4} \mathrm{CH}_{3}\right)$ & $>128(6.3 \%)$ & 22.6 & NT & $>128(0 \%)$ & NA \\
\hline 7a/7b $(\text { Ptx-CH }-(1 H \text {-imidazol-5-yl }))^{\text {e,f }}$ & 13 & 92.5 & 12 & $>128(4 \%)$ & $>9.7$ \\
\hline 22 (iso-Ptx-H) & 14 & 100.0 & 44 & 52 & 3.6 \\
\hline $23\left(\mathrm{Ptx}-\left(2-\mathrm{CH}_{3} \mathrm{O}-\mathrm{Ph}\right)\right)$ & $>82(48 \%)$ & 83.3 & $\mathrm{NT}^{\mathrm{g}}$ & 34 & $\mathrm{NA}^{\mathrm{h}}$ \\
\hline 24 (Ptx-(4-F-Ph)) & $>31(20 \%)$ & -19.0 & NT & $>31(0 \%)$ & NA \\
\hline $25\left(\mathrm{Ptx}-\mathrm{CH}_{3}\right)$ & 15 & 99.0 & NT & 12 & 0.8 \\
\hline $26\left(\mathrm{Ptx}-\mathrm{CH}\left(\mathrm{CH}_{3}\right) \mathrm{CH}_{2} \mathrm{CH}_{3}\right)$ & $>103(0 \%)$ & 59.1 & NT & 73 & NA \\
\hline $27\left(\operatorname{Ptx}-\left(\mathrm{CH}_{2}\right)_{2} \mathrm{SCH}_{3}\right)$ & 106.8 & 90.0 & NT & $>128(0 \%)$ & $>1.2$ \\
\hline $28\left(\mathrm{Ptx}-\mathrm{CH}_{2} \mathrm{Ph}\right)$ & $>128(28 \%)$ & 13.7 & NT & 82 & NA \\
\hline $29\left(\mathrm{Ptx}-\mathrm{CHOHCH}{ }_{3}\right)$ & 53 & 99.8 & NT & 24 & 0.5 \\
\hline $30\left(\mathrm{Ptx}-\left(\mathrm{CH}_{2}\right)_{2} \mathrm{CO}_{2} \mathrm{CH}_{3}\right)$ & $>128(81 \%)$ & 99.1 & 62 & 31 & NA \\
\hline $31\left(\mathrm{Ptx}-\left(\mathrm{CH}_{2}\right)_{2} \mathrm{CO}_{2} \mathrm{H}\right)$ & 95 & 99.1 & NT & 102 & 1.1 \\
\hline $32\left(\mathrm{Ptx}-\left(\mathrm{CH}_{2}\right)_{2} \mathrm{CONH}_{2}\right)$ & 29 & 99.0 & NT & 54 & 1.9 \\
\hline $33\left(\mathrm{Ptx}-\mathrm{CH}_{2} \mathrm{CONH}_{2}\right)$ & 59 & 97.1 & NT & 45 & 0.8 \\
\hline Rifampin & 0.04 & NT & 0.93 & NT & NA \\
\hline Isoniazid & 0.03 & NT & $>128(65 \%)$ & NT & NA \\
\hline PA824 & 0.15 & NT & NT & NT & NA \\
\hline
\end{tabular}

${ }^{a}$ Microplate Alamar blue assay against $M$. tuberculosis $\mathrm{H}_{37} \mathrm{Rv}$ (ATCC 27294); ${ }^{\mathrm{b}}$ Low-oxygen-recovery assay against M. tuberculosis $\mathrm{H}_{37} \mathrm{Rv} ;{ }^{c} \%$ inhibition at $64 \mu \mathrm{g} / \mathrm{mL}$; ${ }^{d}$ Selectivity Index $=\left(\right.$ Vero Cell $\left.\mathrm{IC}_{50}\right) /$ (M. tuberculosis MIC); ${ }^{\mathrm{e}} 3: 1$ ratio of regioisomers $(\mathbf{7 a} / \mathbf{7 b}) ;{ }^{\mathrm{f}} \mathbf{7 a} / \mathbf{7 b}$ also displayed activity against MRSA $\left(\mathrm{IC}_{50} 3 \mu \mathrm{g} / \mathrm{mL}\right.$ ), VRE (IC ${ }_{50} 7.5 \mu \mathrm{g} / \mathrm{mL}$ ), M. smegmatis (MIC $4 \mu \mathrm{g} / \mathrm{mL}$ ) and M. diernhoferi (MIC $2 \mu \mathrm{g} / \mathrm{mL}$ ) and was inactive against $C$. albicans and $P$. aeruginosa at $128 \mu \mathrm{g} / \mathrm{mL} ;{ }^{\mathrm{g}} \mathrm{NT}=$ not tested; ${ }^{\mathrm{h}} \mathrm{NA}=$ not applicable.

As a measure of potential toxicity the $\mathrm{IC}_{50}$ values of the pseudopteroxazoles against Vero cells [21] were determined, and the selectivity index was calculated (Vero cell $\mathrm{IC}_{50} /$ M. tuberculosis $\mathrm{H}_{37} \mathrm{Rv} \mathrm{MIC}$ ). Only four semi-synthetic pseudopteroxazoles were non-toxic to Vero cells at $128 \mu \mathrm{g} / \mathrm{mL}$ : pseudopteroxazole (1), homopseudopteroxazole (2), the methionine derivative (27) and the histidine derivative $(\mathbf{7 a} / \mathbf{7 b}, 4 \%$ toxicity at $128 \mu \mathrm{g} / \mathrm{mL})$. Of these, two $(\mathbf{1}$ and $\mathbf{7 a} / \mathbf{7 b})$ exhibited antitubercular activity resulting in selectivity indices $>8.6$. The cytotoxicity result for $\mathbf{1}$ is comparable to that observed with "natural" pseudopteroxazole (1), which was reported to show no significant cytotoxicity against the NCI-60 cell line assay [6]. Interestingly, isopseudopteroxazole (22) displayed toxicity towards the Vero cells $\left(\mathrm{IC}_{50} 52 \mu \mathrm{g} / \mathrm{mL}\right.$ ), otherwise this regioisomer exhibited very similar antimicrobial activity to $\mathbf{1}$.

The pseudopteroxazoles were also tested at a single point concentration $(64 \mu \mathrm{g} / \mathrm{mL})$ in the low-oxygen-recovery assay (LORA), a model of NRP-TB [22]. Selected active compounds were 
further tested to determine LORA MICs; 7a/7b showed the strongest activity, with an MIC of 12 $\mu \mathrm{g} / \mathrm{mL}$ (Table 1). As antibiotics acting on the cell wall are typically not active against NRP-TB, the LORA activity exhibited by pseudopteroxazole and several semi-synthetic congeners suggests that the target of these compounds is not the cell wall [22].

The semi-synthetic histidine derivative $(\mathbf{7 a} / \mathbf{7 b})$ is the most promising of the pseudopteroxazoles as it was non-toxic, exhibited potent broad-spectrum Gram-positive antibiotic activity and was the most active compound in assays against replicating and NRP-TB (MABA and LORA, respectively). While the MIC of $\mathbf{7 a} / \mathbf{7} \mathbf{b}$ against $M$. tuberculosis $\mathrm{H}_{37} \mathrm{Rv}$ was moderate $(13 \mu \mathrm{g} / \mathrm{mL}$ or $34 \mu \mathrm{M})$ in comparison to the first line drugs isoniazid and rifampin, its activity compares favorably to other first and second line TB treatments such as ethambutol (4.6-9.2 $\mu \mathrm{M})$, kanamycin $(2.5-10.3 \mu \mathrm{M})$, capreomycin $(0.94-3.7 \mu \mathrm{M})$ and cycloserine $(122-490 \mu \mathrm{M})$ [23]. One of the most promising attributes of $7 \mathbf{a} / 7 \mathbf{b}$ was that it showed greater potency in LORA (LORA MIC $12 \mu \mathrm{g} / \mathrm{mL}$ or $31 \mu \mathrm{M}$ ) compared to 1 (LORA MIC $50 \mu \mathrm{g} / \mathrm{mL}$ or $162 \mu \mathrm{M})$. Activity against NRP-TB is highly desirable given this phenotype contributes to lengthy treatment regimens leading to poor patient compliance ultimately translating into increased TB transmission rates and selection for drug-resistant strains [4]. As shortening of treatment times is a key goal of current $\mathrm{TB}$ chemotherapeutic research, this compound may represent a starting point for developing drugs that are more efficacious towards latent TB infections [1].

Recently a diterpene that is structurally related to pseudopterosins has been shown to possess activity against $M$. tuberculosis $\mathrm{H}_{37} \mathrm{Rv}$ and a multidrug-resistant strain [24]. These examples suggest that the semi-synthetic pseudopteroxazole congeners may also display activity against drug-resistant strains. Thus, we determined MICs of 1 against six isogenic mono-resistant M. tuberculosis $\mathrm{H}_{37} \mathrm{Rv}$ strains (Table 2). In our study the six strains tested were singly-resistant to a structurally diverse group of antibiotics targeting a variety of cellular targets. The aminoglycosides streptomycin and kanamycin target the 30S ribosome, the fluoroquinolone moxifloxacin targets DNA gyrase, the ansamycin antibiotic rifampin targets RNA polymerase and the small heterocyclic antibiotics isoniazid and cycloserine inhibit cell wall biosynthesis, albeit via distinct mechanisms [25-27]. Pseudopteroxazole exhibited virtually identical activity against wild-type and antibiotic resistant strains. While $\mathbf{1}$ was significantly less potent than rifampin and isoniazid none of the antibiotic resistant strains exhibited cross-resistance to $\mathbf{1}$, suggesting that it may exert its antimicrobial activity via a unique mode of action.

Table 2. Susceptibility of mono-antibiotic resistant $M$. tuberculosis $\mathrm{H}_{37} \mathrm{Rv}$ isogenic strains to pseudopteroxazole, rifampin and isoniazid.

\begin{tabular}{lccccccc}
\hline & \multicolumn{7}{c}{$\mathbf{M A B A}^{\mathbf{a}} \mathbf{M I C}[\boldsymbol{\mu g} / \mathbf{m L}]$} \\
\cline { 2 - 8 } Compound & $\mathbf{H}_{\mathbf{3} 7 \mathbf{R v}}$ & $\mathbf{R M P}^{\mathbf{r}}$ & $\mathbf{I N H}^{\mathbf{r}}$ & $\mathbf{S M}^{\mathbf{r}}$ & $\mathbf{K M}^{\mathbf{r}}$ & $\mathbf{C S}^{\mathbf{r}}$ & $\mathbf{M O X}^{\mathbf{r}}$ \\
\hline $\mathbf{1}$ & 7 & 8 & 8 & 14 & 16 & 14 & 8 \\
Rifampin & 0.03 & $>3.3$ & 0.02 & 0.08 & 0.02 & 0.01 & 0.02 \\
Isoniazid & 0.03 & 0.12 & $>1.10$ & 0.13 & 0.13 & 0.12 & 0.03 \\
\hline
\end{tabular}

${ }^{a}$ Microplate Alamar blue assay against wild-type M. tuberculosis $\mathrm{H}_{37} \mathrm{Rv}\left(\mathrm{H}_{37} \mathrm{Rv}\right)$ and M. tuberculosis $\mathrm{H}_{37} \mathrm{Rv}$ isogenic strains resistant to rifampin $\left(\mathrm{RMP}^{\mathrm{r}}\right)$, isoniazid $\left(\mathrm{INH}^{\mathrm{r}}\right)$, streptomycin $\left(\mathrm{SM}^{\mathrm{r}}\right)$, kanamycin $\left(\mathrm{KM}^{\mathrm{r}}\right)$, cycloserine $\left(\mathrm{CS}^{\mathrm{r}}\right)$ and moxifloxacin $\left(\mathrm{MOX}^{\mathrm{r}}\right)$. 
2.2.2. Anti-Microbial Activity of Semi-Synthetic Pseudopteroquinoxalines, Pseudopterosins, and the Prenylated Mimics

The biological data of the pseudopterosin derivatives (including the pseudopteroquinoxalines) and of the prenylated aromatic mimics of pseudopterosins are summarized in Table 3. These compounds were tested in vitro against MRSA, VRE, M. smegmatis (ATCC 12051), and M. diernhoferi (ATCC 19340) using microbroth dilution antibiotic susceptibility assays. The compounds were also assessed for activity against $M$. tuberculosis, Vero cells and in the LORA. Natural pseudopterosins G-J (3a-d) showed the strongest activity against all pathogens, and exhibited low toxicity towards Vero cells. The mono-methyl ether (9) retained some activity against all pathogens; however, all other semi-synthetic derivatives showed significantly reduced activity against one or more organisms. Pseudopteroquinoxaline (5) was moderately active against the three mycobacteria; however, it was toxic towards the Vero cells.

Table 3. Antibacterial, LORA and cytotoxicity activities of pseudopterosins, pseudopteroquinoxalines and structural mimics in vitro.

\begin{tabular}{|c|c|c|c|c|c|c|c|c|c|}
\hline \multirow[b]{2}{*}{ Compound } & \multicolumn{2}{|c|}{$\mathrm{IC}_{50}[\mu \mathrm{g} / \mathrm{mL}]$} & \multicolumn{3}{|c|}{ MIC $[\mu \mathrm{g} / \mathrm{mL}](\%$ inh $)$} & \multirow[b]{2}{*}{ 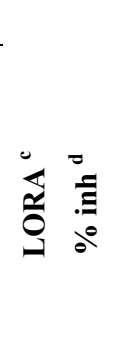 } & \multirow[b]{2}{*}{ 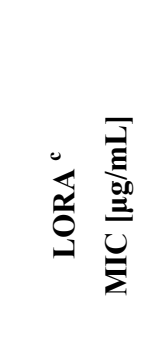 } & \multirow[b]{2}{*}{ 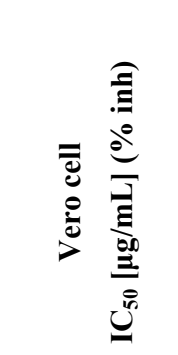 } & \multirow[b]{2}{*}{$\ddot{\omega}$} \\
\hline & 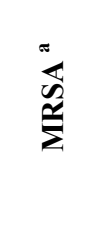 & 뇔 & 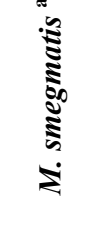 & 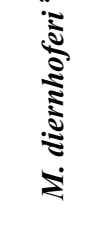 & 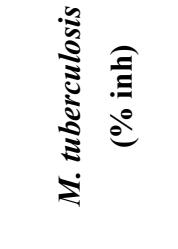 & & & & \\
\hline 3a- $\mathbf{d}^{\mathrm{f}}$ (Ps G-J mixture $)$ & $<1$ & $<1$ & 2 & 2 & 30 & 97.9 & $\mathrm{NT}^{\mathrm{g}}$ & $>128(32 \%)$ & $>4.3$ \\
\hline $4^{\mathrm{f}}(\mathrm{Ps} \mathrm{G}-\mathrm{J}$ aglycone $)$ & 88 & $>128$ & 8 & 8 & $>128(86 \%)$ & 53.1 & $\mathrm{NT}^{\mathrm{g}}$ & 50 & $\mathrm{NA}^{\mathrm{h}}$ \\
\hline 5 (pseudopteroquinoxaline) ${ }^{\mathrm{f}}$ & $>128$ & $>128$ & 16 & 64 & 29 & 99.9 & NT & 22 & 0.8 \\
\hline 6 (Me ether of pseudopteroquinoxaline) & NT & NT & NT & NT & 84 & 99.9 & NT & 15 & 0.2 \\
\hline $\mathbf{8}^{\mathrm{f}}$ (Ps G-J mono-pentyl ether) & 47 & 22 & $>128$ & $>128$ & $>128(85 \%)$ & 35.1 & NT & 49 & NA \\
\hline $9^{\mathrm{f}}$ (Ps G-J mono-methyl ether) & 9 & 12 & 4 & 4 & 30 & 99.7 & 52 & $>128(26 \%)$ & $>4.3$ \\
\hline $10{ }^{\mathrm{f}}$ (Ps G-J di-methyl ether) & $>128$ & 25 & $>64$ & $>64$ & $>128(63 \%)$ & 77.5 & NT & 51 & NA \\
\hline $11^{\mathrm{f}}$ (triflate) & $>128$ & $>128$ & $>64$ & $>64$ & $>128(44 \%)$ & 37.5 & NT & 51 & NA \\
\hline $12^{\mathrm{f}}$ (carbamate) & $>128$ & 70 & 64 & $>64$ & $>128(77 \%)$ & 80.0 & NT & $>128(0 \%)$ & NA \\
\hline $14^{\mathrm{f}}$ (mono-prenylated mimic) & $>128$ & $>128$ & 128 & 64 & $>128(24 \%)$ & -4.7 & NT & 44 & NA \\
\hline $15^{\mathrm{f}}$ (di-prenylated mimic) & 20 & 3 & 8 & 8 & 59 & 99.7 & 58 & 64 & 1.1 \\
\hline $16^{\mathrm{f}}$ (tri-prenylated mimic) & $>128$ & 3 & $>128$ & 8 & 56 & 79.7 & NT & $>128(29 \%)$ & $>2.3$ \\
\hline 20 (galactoside of 14) & $>128$ & $>128$ & $>128$ & $>128$ & $>128(1.4 \%)$ & -24.8 & NT & 82 & NA \\
\hline Vancomycin & 1.23 & NT & NT & NT & NT & NT & NT & NT & NA \\
\hline Rifampin & NT & 0.88 & 4 & 4 & 0.04 & NT & 0.93 & NT & NA \\
\hline Isoniazid & NT & NT & NT & NT & 0.03 & NT & $>128(65 \%)$ & NT & NA \\
\hline PA824 & NT & NT & NT & NT & 0.15 & NT & NT & NT & NA \\
\hline
\end{tabular}

${ }^{\mathrm{a}}$ Microbroth dilution antibiotic susceptibility assay; ${ }^{\mathrm{b}}$ Microplate Alamar blue assay against M. tuberculosis $\mathrm{H}_{37} \mathrm{Rv}$ (ATCC 27294); ${ }^{\mathrm{c}}$ Low-oxygen-recovery assay against M. tuberculosis $\mathrm{H}_{37} \mathrm{Rv}$ (ATCC 27294); ${ }^{\mathrm{d}} \%$ inhibition at $64 \mu \mathrm{g} / \mathrm{mL}$; ${ }^{\mathrm{e}}$ Selectivity Index $=\left(\right.$ Vero Cell $\left.\mathrm{IC}_{50}\right) /($ M. tuberculosis $\mathrm{MIC}) ;{ }^{\mathrm{f}}$ No inhibitory activity was observed against $C$. albicans nor against $P$. aeruginosa at $128 \mu \mathrm{g} / \mathrm{mL} ;{ }^{\mathrm{g}} \mathrm{NT}=$ not tested; ${ }^{\mathrm{h}} \mathrm{NA}=$ not applicable. 
The activity of the prenylated aromatic mimics is interesting: the mono-prenylated compound (14) was only weakly active against $M$. smegmatis and $M$. diernhoferi; the tri-prenylated compound (16) showed moderate activity against $M$. diernhoferi, and was also active against VRE and M. tuberculosis; the di-prenylated compound (15) was the most active as it showed good to moderate activity against all bacteria with an $\mathrm{IC}_{50}$ of $3 \mu \mathrm{g} / \mathrm{mL}$ against VRE. To provide a glycoside mimic of pseudopterosins, the galactoside derivative $\mathbf{2 0}$ was synthesized from 14. This synthetic galactoside was less active than the parent prenylated mimic and no additional glycosides were synthesized following unsuccessful glycosylation attempts utilizing the di-prenylated compound (15). The activity of the prenylated aromatics hints at the possibility of a simpler pharmacophore than the natural diterpene skeleton. However, more work is required here as it does not necessarily follow that these mimics operate through the same mechanism of action as the pseudopterosins/pseudopteroxazoles.

\subsubsection{Relevance of the Use of Model Mycobacteria}

Due to the challenges associated with cultivating M. tuberculosis (slow growth rate, biosafety risk, biosafety level 3 containment requirements) we initially used two fast growing mycobacteria, M. smegmatis and M. diernhoferi, as model organisms to evaluate the antimycobacterial activity of the compounds described herein. The usefulness of fast growing mycobacteria to detect compounds inhibitory to the growth of TB, particularly the widely used $M$. smegmatis, has recently been questioned. In a comprehensive study of the relative activity of 5000 compounds against $M$. smegmatis and $M$. tuberculosis, $50 \%$ of compounds active against $M$. tuberculosis were not detected as active against M. smegmatis [27]. Despite this disparity, the use of fast growing mycobacterial models continue to have utility as a whole cell screen against $M$. smegmatis identified the promising new diarylquinoline, TMC207, which is currently in Phase II-III clinical trials for the treatment of multidrug-resistant TB [1]. In the evaluation of the series of pseudopteroxazole congeners the model mycobacteria were good predictors of antimycobacterial activity (Tables 1 and 3, and previously published data [11]). There were no instances of false-negative predictions (i.e., the model organisms were insensitive to a compound which inhibited the growth of $M$. tuberculosis). However, there were a few instances where the model organisms predicted activity which was not mirrored by M. tuberculosis in the MABA $(4,27,28,31)$. Interestingly, in three of these cases significant activity was observed in the LORA. These observations suggest that model mycobacteria can be a reliable predictor of M. tuberculosis activity for a particular series of molecules.

\section{Experimental Section}

\subsection{General Experimental Procedures}

The MABA, LORA and Vero cell assays were all conducted by the Institute for Tuberculosis Research following published protocols [20-22]. NMR spectra were obtained on a Bruker Avance III $600 \mathrm{MHz}$ NMR spectrometer operating at 600 and $150 \mathrm{MHz}$ for ${ }^{1} \mathrm{H}$ and ${ }^{13} \mathrm{C}$, respectively. Chemical shifts $(\delta)$ are reported in ppm and were referenced to residual solvent signals: $\mathrm{CDCl}_{3}\left(\delta_{\mathrm{H}} 7.26 ; \delta_{\mathrm{C}} 77.0\right)$, $\left(\mathrm{CD}_{3}\right)_{2} \mathrm{SO}\left(\delta_{\mathrm{H}} 2.50 ; \delta_{\mathrm{C}} 39.52\right), \mathrm{CD}_{3} \mathrm{OD}\left(\delta_{\mathrm{H}} 3.31 ; \delta_{\mathrm{C}} 49.0\right), \mathrm{C}_{6} \mathrm{D}_{6}\left(\delta_{\mathrm{H}} 7.15 ; \delta_{\mathrm{C}} 128.02\right)$. The phrase "standard work up procedure" refers to the following protocol: the organic phase is dried $\left(\mathrm{MgSO}_{4}\right)$, 
filtered through glass wool, and then concentrated in vacuo. All other general experimental procedures and the syntheses of compounds $\mathbf{1}, \mathbf{2}, \mathbf{4}, \mathbf{\&} 2 \mathbf{2 2}-\mathbf{3 3}$ are identical to those previously described [11].

\subsection{Synthesis}

\subsubsection{Synthesis of Pseudopteroquinoxaline (5)}

A sample of pseudopterosin $\mathrm{G}-\mathrm{J}(\mathbf{3 a}-\mathbf{d}, 20 \mathrm{mg}, 0.041 \mathrm{mmol})$ was refluxed in methanolic $\mathrm{HCl}(1.5 \mathrm{~N}$, $10 \mathrm{~mL}$ ) under $\mathrm{N}_{2}$ for $2.5 \mathrm{~h}$. The crude mixture was then partitioned between EtOAc and $\mathrm{H}_{2} \mathrm{O}$ and the EtOAc phase was concentrated in vacuo to give the crude aglycone (4). This material was dissolved in EtOH $(15 \mathrm{~mL})$ and air was bubble through the sample for $10 \mathrm{~min}$. Ethylenediamine (50 $\mu \mathrm{L}$, excess) and $\mathrm{Ag}_{2} \mathrm{O}$ (14 mg, $\left.0.065 \mathrm{mmol}\right)$ were then added and the reaction was refluxed for $1.5 \mathrm{~h}$. The reaction mixture was then filtered through Celite and partitioned between EtOAc and $\mathrm{H}_{2} \mathrm{O}$. The EtOAc phase was subjected to the standard work up procedure and then purified by flash chromatography (Silica, hexane $\rightarrow$ MTBE gradient) to give 5 ( $2 \mathrm{mg}, 0.0063 \mathrm{mmol}, 15 \%$ over two steps).

5: yellow oil; $[\alpha]^{25}+103\left(c 0.03, \mathrm{CHCl}_{3}\right)$; IR $v_{\max } 2921,2858,1470 \mathrm{~cm}^{-1} ;{ }^{1} \mathrm{H} \mathrm{NMR}\left(\mathrm{CDCl}_{3}, 600 \mathrm{MHz}\right)$ $\delta 8.74$ (m, 2H, H-20, H-21), 5.04 (d, 1H, $J=9.1 \mathrm{~Hz}, \mathrm{H}-14), 4.11$ (app. q, 1H, $J=8.5 \mathrm{~Hz}, \mathrm{H}-1$ ), 4.06 (app. q, 1H, $J=7.3 \mathrm{~Hz}, \mathrm{H}-7), 2.64$ (s, 3H, H-20), 2.39-2.33 (m, 1H), 2.28-2.23 (m, 1H), 2.23-2.18 (m, 1H), 2.17-2.11 (m, 1H), 1.82 (s, 3H, H-17), 1.70 (s, 3H, H-16), 1.54 (m, 1H), 1.42-1.40 (m, 2H), 1.39 (d, 3H, $J=6.9 \mathrm{~Hz}, \mathrm{H}-19), 1.37-1.32(\mathrm{~m}, 1 \mathrm{H}), 1.26-1.24(\mathrm{~m}, 1 \mathrm{H}), 1.11(\mathrm{~d}, 3 \mathrm{H}, J=6.2 \mathrm{~Hz}, \mathrm{H}-18)$ $1.14-1.09(\mathrm{~m}, 1 \mathrm{H}) ;{ }^{13} \mathrm{C} \mathrm{NMR}\left(\mathrm{CDCl}_{3}, 150 \mathrm{MHz}\right) \delta 142.1,142.0,141.9,141.3,141.0,140.1,137.0$, $132.2,129.7,129.7,44.3,39.5,37.4,33.8,30.7,28.5,26.8,25.5,24.7,20.4,17.7,12.8$; APCIMS $m / z 321[\mathrm{M}+\mathrm{H}]^{+}$; HRMS-ES $m / z[\mathrm{M}+\mathrm{H}]^{+} 321.2313$ (calcd for $\mathrm{C}_{22} \mathrm{H}_{29} \mathrm{~N}_{2}, 321.2325$ ).

\subsubsection{Synthesis of 14,15-Dihydro-15-methoxy-pseudopteroquinoxaline (6)}

To a solution of the pseudopterosin aglycone $(4,26.3 \mathrm{mg}, 0.088 \mathrm{mmol})$ in DCM $(10 \mathrm{~mL}+100 \mu \mathrm{L}$ $\mathrm{H}_{2} \mathrm{O}$ ) was added Dess-Martin periodinane $(68 \mathrm{mg}, 0.16 \mathrm{mmol})$. After stirring for $15 \mathrm{~min}, \mathrm{MeOH}(2 \mathrm{~mL})$ and ethylenediamine $(1 \mathrm{~mL})$ were added. After another $45 \mathrm{~min}$ the solvent was removed in vacuo, and then isopropyl alcohol was added $(20 \mathrm{~mL})$. After refluxing overnight additional ethylenediamine $(200 \mu \mathrm{L})$ was added and the solution was refluxed for a further $24 \mathrm{~h}$. The reaction products were partitioned between EtOAc and $\mathrm{H}_{2} \mathrm{O}$ and the organic phase was subjected to the standard work up procedure to give an orange brown gum $(31.8 \mathrm{mg})$. Purification by flash chromatography (diol modified silica, hexane $\rightarrow$ MTBE gradient) yielded the quinoxaline (5, $4.6 \mathrm{mg}, 16 \%)$ and the methyl ether $(6,1.6 \mathrm{mg}, 5 \%)$.

6: amorphous semi solid; $[\alpha]^{25}-5.0\left(c \quad 0.08, \mathrm{CHCl}_{3}\right)$; IR $v_{\max } 2925,2866,1470,1079 \mathrm{~cm}^{-1}$; ${ }^{1} \mathrm{H}$ NMR $\left(\mathrm{CDCl}_{3}, 600 \mathrm{MHz}\right) \delta 8.76$ (s, 2H, H-20, H-21), 3.89 (app. q, $\left.1 \mathrm{H}, J=6.9 \mathrm{~Hz}\right), 3.71(\mathrm{~m}, 1 \mathrm{H})$, 3.20 (s, 3H, OMe), 2.79 (s, 3H, H-20), 2.49 (m, 1H), 2.21-2.15 (m, 3H), 1.89 (dd, 1H, J=9.5, $14.5 \mathrm{~Hz}$, H-14-a), 1.68-1.62 (m, 2H), 1.54-1.50 (m, 1H), 1.41 (d, 3H, $J=6.9$ Hz, H-19), 1.27 (s, 6H), 1.26 (m, 2H), $1.13(\mathrm{~d}, 3 \mathrm{H}, J=6.5 \mathrm{~Hz}) ;{ }^{13} \mathrm{C} \mathrm{NMR}\left(\mathrm{CDCl}_{3}, 150 \mathrm{MHz}\right) \delta 144.7,142.3,141.8,141.6,141.3,140.4$, 136.5, 129.8, 75.3 (C-15), 49.2 (C-23), 48.6 (C-14), 42.3, 38.2, 34.7, 32.2, 30.3, 29.4, 25.8, 25.7, 25.4, 24.0, 21.0. 12.6; APCIMS $m / z 353[\mathrm{M}+\mathrm{H}]^{+}$; HRMS-ES $m / z[\mathrm{M}+\mathrm{H}]^{+} 353.2582$ (calcd for $\left.\mathrm{C}_{23} \mathrm{H}_{33} \mathrm{~N}_{2} \mathrm{O}, 353.2587\right)$. 
3.2.3. Synthesis of 21-((1H-Imidazol-5-yl)methyl)-pseudopteroxazole (7a) and 21-((1H-Imidazol-5-yl)methyl)-isopseudopteroxazole (7b)

The pseudopteroxazole C-21 (1H-imidazol-4-yl)methyl derivatives (7a and 7b) were synthesized from the pseudopterosin aglycone (4, $193 \mathrm{mg}, 0.64 \mathrm{mmol}), \mathrm{Ag}_{2} \mathrm{CO}_{3}$ (1.4 equiv.) and histidine (6.7 equiv.) following the previously reported general procedure [11]. After purification by flash chromatography (diol modified silica, hexane $\rightarrow$ MTBE gradient) the product was obtained in $23 \%$ isolated yield (57.5 mg, 2.4:1 ratio of $\mathbf{7 a} / \mathbf{7 b}$ ). A portion of this material was subjected to RP-HPLC (Phenomenex, phenylhexyl, $5 \mu \mathrm{m}, 250 \times 10 \mathrm{~mm}, 2.9 \mathrm{~mL} / \mathrm{min})$ eluted with $\mathrm{MeOH}: \mathrm{H}_{2} \mathrm{O}: \mathrm{HCO}_{2} \mathrm{H}(70: 30: 0.1)$. While the regioisomers eluted as one asymmetric peak (19.8 to $20.7 \mathrm{~min}$ ), peak shaving lead to the isolation of an enriched fraction (3:1 ratio of normal to inverse regioisomer), which was the material used for biological evaluation.

7a/7b (3:1 ratio): orange immobile oil; $[\alpha]^{25}+129.4\left(c\right.$ 0.09, $\left.\mathrm{CHCl}_{3}\right)$; IR $v_{\max } 2948,2921,2856$, 1446, $1085 \mathrm{~cm}^{-1}$; ${ }^{1} \mathrm{H}$ and ${ }^{13} \mathrm{C}$ NMR see Supplementary Table S1. APCIMS m/z $390[\mathrm{M}+\mathrm{H}]^{+}$; MSMS spectrum see Supplementary Figure S9; HRMS-ES $m / z[\mathrm{M}+\mathrm{H}]^{+} 390.2549$ (calcd for $\left.\mathrm{C}_{25} \mathrm{H}_{32} \mathrm{~N}_{3} \mathrm{O}, 390.2540\right)$.

\subsubsection{Synthesis of 10-Pentoxy-pseudopterosin G-J Aglycone (8)}

A solution of pseudopterosins $\mathrm{G}-\mathrm{J}(\mathbf{3 a}-\mathbf{d}, 102 \mathrm{mg}, 0.2 \mathrm{mmol}), \mathrm{K}_{2} \mathrm{CO}_{3}(1 \mathrm{~g}$, excess $)$ and iodopentane ( $2 \mathrm{~mL}$, excess) in anhydrous acetone was refluxed under $\mathrm{N}_{2}$ for $18 \mathrm{~h}$. The products were then partitioned between EtOAc and $\mathrm{H}_{2} \mathrm{O}$ and subjected to the standard work up procedure to give an orange/brown oil $(127 \mathrm{mg})$. This crude product was then dissolved in $1.5 \mathrm{M} \mathrm{HCl}$ in $\mathrm{MeOH}(10 \mathrm{~mL})$ and refluxed under $\mathrm{N}_{2}$ for $2 \mathrm{~h}$. The products were partitioned between EtOAc and $\mathrm{H}_{2} \mathrm{O}$ and the organic subjected to the standard work up procedure to yield the crude product, which was then purified by flash chromatography $\left(\mathrm{C} 18, \mathrm{H}_{2} \mathrm{O} \rightarrow \mathrm{MeOH}\right.$ gradient $)$ to yield the pentyl ether $(8)(40.3 \mathrm{mg}, 0.11 \mathrm{mmol}$, $52 \%$ over 2 steps).

8: immobile oil; $[\alpha]^{25}+71.6\left(c\right.$ 0.787, $\left.\mathrm{CHCl}_{3}\right)$; IR $v_{\max } 3523,2924,2857,1456,1056 \mathrm{~cm}^{-1}$; ${ }^{1} \mathrm{H}$ NMR $\left(\mathrm{CDCl}_{3}, 600 \mathrm{MHz}\right) \delta 5.70(\mathrm{~s}, 1 \mathrm{H}), 4.97(\mathrm{~d}, 1 \mathrm{H}, J=9.2 \mathrm{~Hz}), 3.84(\mathrm{~m}, 1 \mathrm{H}), 3.75(\mathrm{~m}, 1 \mathrm{H}), 3.67(\mathrm{~m}, 1 \mathrm{H})$, $3.17(\mathrm{~m}, 1 \mathrm{H}), 2.17(\mathrm{~m}, 1 \mathrm{H}), 2.07(\mathrm{~s}, 3 \mathrm{H}), 2.06-2.02(\mathrm{~m}, 2 \mathrm{H}), 1.97(\mathrm{~m}, 1 \mathrm{H}), 1.80(\mathrm{~m}, 2 \mathrm{H}), 1.73(\mathrm{~s}, 3 \mathrm{H})$, $1.68(\mathrm{~s}, 3 \mathrm{H}), 1.46(\mathrm{~m}, 2 \mathrm{H}), 1.40(\mathrm{~m}, 2 \mathrm{H}), 1.34-1.31(\mathrm{~m}, 1 \mathrm{H}), 1.30(\mathrm{~d}, 3 \mathrm{H}, J=6.8 \mathrm{~Hz}), 1.23-1.21$ $(\mathrm{m}, 2 \mathrm{H}), 1.03(\mathrm{~d}, 3 \mathrm{H}, J=6.0 \mathrm{~Hz}), 0.95(\mathrm{~m}, 1 \mathrm{H}), 0.95(\mathrm{t}, 3 \mathrm{H}, 7.2 \mathrm{~Hz}) ;{ }^{13} \mathrm{C} \mathrm{NMR}\left(\mathrm{CDCl}_{3}, 150 \mathrm{MHz}\right)$ $\delta 144.8,142.8,135.6,131.3,129.8,128.3,126.7,125.5,73.6,44.7,40.2,37.0,34.0,32.1,30.1,28.8$, 28.2, 27.8, 25.4, 23.0, 22.6, 20.0, 17.5, 14.0, 12.7; APCIMS $m / z 371[\mathrm{M}+\mathrm{H}]^{+}$; HRMS-ES $m / z$ $[\mathrm{M}+\mathrm{H}]^{+} 371.2942$ (calcd for $\mathrm{C}_{25} \mathrm{H}_{39} \mathrm{O}_{2}, 371.2945$ ).

\subsubsection{Synthesis of 9,10-Dimethoxy-pseudopterosin G-J Aglycone (10)}

A stirred solution of 9 [19] $(25.5 \mathrm{mg}, 0.083 \mathrm{mmol})$ in dry THF $(5 \mathrm{~mL})$, under $\mathrm{N}_{2}$, was allowed to react with an excess of $\mathrm{NaH}$ for $2 \mathrm{~h}$. Iodomethane ( $200 \mu \mathrm{L}$, excess) was then added and the solution was left stirring at room temperature overnight. The reaction was then carefully quenched with $\mathrm{MeOH}$ $(1 \mathrm{~mL})$, and excess iodomethane was removed under a stream of $\mathrm{N}_{2}$. The products were then partitioned between EtOAc and $\mathrm{H}_{2} \mathrm{O}$. The EtOAc fraction was subjected to the standard work up procedure to give 
the crude product which was purified by flash chromatography (silica, hexane $\rightarrow \mathrm{MTBE}$ gradient) to yield the desired dimethyl ether (10) (18.2 $\mathrm{mg}, 0.055 \mathrm{mmol}, 67 \%)$.

10: amorphous solid; $[\alpha]^{25}+69.5\left(c\right.$ 0.573, $\left.\mathrm{CHCl}_{3}\right)$; IR $v_{\max } 2924,2861,1460,1069 \mathrm{~cm}^{-1}$; ${ }^{1} \mathrm{H}$ NMR $\left(\mathrm{CDCl}_{3}, 600 \mathrm{MHz}\right) \delta 4.99(\mathrm{~d}, 1 \mathrm{H}, J=9.2 \mathrm{~Hz}), 3.88(\mathrm{~s}, 3 \mathrm{H}), 3.81(\mathrm{~s}, 3 \mathrm{H}), 3.73(\mathrm{q}, 1 \mathrm{H}, J=8.8 \mathrm{~Hz}), 3.26$ (m, 1H), 2.15-2.05 (m, 3H), $2.11(\mathrm{~s}, 3 \mathrm{H}), 2.00(\mathrm{~m}, 1 \mathrm{H}), 1.76$ (br s, 3H), 1.71 (br s, 3H), $1.39(\mathrm{~m}, 1 \mathrm{H})$, $1.31-1.23(\mathrm{~m}, 2 \mathrm{H}), 1.28(\mathrm{~d}, 3 \mathrm{H}, J=6.9 \mathrm{~Hz}), 1.07(\mathrm{~d}, 3 \mathrm{H}, J=6.0 \mathrm{~Hz}), 0.98(\mathrm{~m}, 1 \mathrm{H}) ;{ }^{13} \mathrm{C} \mathrm{NMR}\left(\mathrm{CDCl}_{3}\right.$, $150 \mathrm{MHz}) \delta 149.4,149.0,135.3,134.0,133.0,130.9,128.5,128.4,60.1,59.8,44.0,40.1,37.3,34.0$, 31.3, 28.3, 27.5, 25.4, 24.3, 20.0, 17.5, 12.1; APCIMS m/z $329[\mathrm{M}+\mathrm{H}]^{+}$; HRMS-ES $m / z[\mathrm{M}+\mathrm{H}]^{+}$ 329.2459 (calcd for $\mathrm{C}_{22} \mathrm{H}_{33} \mathrm{O}_{2}, 329.2475$ ).

\subsubsection{Synthesis of 9-Trifluoromethylsulfonyloxy-10-methoxy-pseudopterosin G-J Aglycone (11)}

Triflic anhydride $(6 \mathrm{mmol})$ in DCM was added to a stirred, ice-cooled solution of 9 (178 $\mathrm{mg}$, $0.56 \mathrm{mmol})$ and Hunig's base $(2 \mathrm{~mL})$ in dry toluene $(8 \mathrm{~mL})$. The reaction was stirred under $\mathrm{N}_{2}$, and allowed to warm to room overnight before being partitioned between DCM and aqueous $\mathrm{HCl}(1 \mathrm{~N})$. The organic phase was subjected to the standard work up procedure to yield the crude triflate; purification was achieved by flash chromatography (silica, hexane $\rightarrow$ EtOAc gradient) to yield the triflate (11, $177 \mathrm{mg}, 0.4 \mathrm{mmol}, 70 \%, \sim 90 \%$ pure by ELSD LCMS). A portion of the product was further purified by RP-HPLC (Phenomenex, phenylhexyl, $5 \mu \mathrm{m}, 250 \times 10 \mathrm{~mm}, 4.0 \mathrm{~mL} / \mathrm{min}$ ) using a gradient of $\mathrm{MeOH} / \mathrm{H}_{2} \mathrm{O}$ (9:1 for $1 \mathrm{~min}$, then to 10:0 over 1-4 min; eluted across 9.9 to $10.25 \mathrm{~min}$ ).

11: amorphous solid; $[\alpha]_{\mathrm{D}}^{25}+62.8\left(c\right.$ 0.205, $\left.\mathrm{CHCl}_{3}\right)$; IR $v_{\max } 2928,2869,1416,1206,1139 \mathrm{~cm}^{-1}$; ${ }^{1} \mathrm{H}$ NMR $\left(\mathrm{CDCl}_{3}, 600 \mathrm{MHz}\right) \delta 4.93(\mathrm{~d}, 1 \mathrm{H}, J=9.3 \mathrm{~Hz}), 3.74(\mathrm{~s}, 3 \mathrm{H}), 3.72(\mathrm{~m}, 1 \mathrm{H}),, 3.23(\mathrm{dd}, 1 \mathrm{H}$, $J=7.2,14.6 \mathrm{~Hz}), 2.18-2.06(\mathrm{~m}, 3 \mathrm{H}), 2.12(\mathrm{~s}, 3 \mathrm{H}), 2.01(\mathrm{~m}, 1 \mathrm{H}), 1.74$ (br s, 3H), 1.70 (br s, 3H), 1.37 $(\mathrm{m}, 1 \mathrm{H}), 1.26-1.21(\mathrm{~m}, 2 \mathrm{H}), 1.25(\mathrm{~d}, 3 \mathrm{H}, J=6.9 \mathrm{~Hz}), 1.04(\mathrm{~d}, 3 \mathrm{H}, J=5.9 \mathrm{~Hz}), 0.97(\mathrm{~m}, 1 \mathrm{H}) ;{ }^{13} \mathrm{C} \mathrm{NMR}$ $\left(\mathrm{CDCl}_{3}, 150 \mathrm{MHz}\right) \delta 147.9,140.1,139.7,136.7,132.6,129.7(2 \times \mathrm{C}), 129.5,118.7(\mathrm{q}, J=320 \mathrm{~Hz})$, 117.6, 60.8, 44.0, 39.8, 37.4, 33.9, 30.9, 28.6, 27.0, 25.4, 23.3, 19.8, 17.6, 12.5; APCIMS $m / z 447$ $[\mathrm{M}+\mathrm{H}]^{+}$; HRMS-ES $m / z[\mathrm{M}+\mathrm{H}]^{+} 447.1804$ (calcd for $\mathrm{C}_{22} \mathrm{H}_{30} \mathrm{~F}_{3} \mathrm{O}_{4} \mathrm{~S}, 447.1811$ ).

\subsubsection{Synthesis of 9-Dimethylcarbamoyloxy-10-methoxy-pseudopterosin G-J Aglycone (12)}

A stirred solution of $9(25.5 \mathrm{mg}, 0.083 \mathrm{mmol})$ in dry THF $(5 \mathrm{~mL})$, under $\mathrm{N}_{2}$, was allowed to react with an excess of $\mathrm{NaH}$ for $2 \mathrm{~h}$. Dimethylcarbamoyl chloride ( $200 \mu \mathrm{L}$, excess) was then added and the solution was stirred overnight. The reaction was then carefully quenched with $\mathrm{MeOH}(1 \mathrm{~mL})$ and the products were portioned between EtOAc and $\mathrm{H}_{2} \mathrm{O}$. The EtOAc fraction was subjected to the standard work up procedure to give the crude product which was purified by flash chromatography (silica, hexane $\rightarrow$ MTBE gradient) to yield the carbamate $(\mathbf{1 2}, 13.7 \mathrm{mg}, 0.035 \mathrm{mmol}, 43 \%)$.

Carbamate (12): amorphous solid; $[\alpha]^{25}{ }_{\mathrm{D}}+110.2$ (c 0.07, $\mathrm{CHCl}_{3}$ ); IR $v_{\max }$ 2924, 2861, 1723 (CO), 1451, 1386, $1164 \mathrm{~cm}^{-1}$; ${ }^{1} \mathrm{H} \mathrm{NMR}\left(\mathrm{CDCl}_{3}, 600 \mathrm{MHz}\right) \delta 4.97$ (d, $\left.1 \mathrm{H}, J=9.2 \mathrm{~Hz}\right), 3.70(\mathrm{~s}, 3 \mathrm{H}), 3.71-3.67$ (m, $1 \mathrm{H}), 3.16(\mathrm{~s}, 3 \mathrm{H}), 3.04(\mathrm{~s}, 3 \mathrm{H}), 3.03(\mathrm{~m}, 1 \mathrm{H}), 2.14-2.10(\mathrm{~m}, 2 \mathrm{H}), 2.07(\mathrm{~s}, 3 \mathrm{H}), 2.07-2.02(\mathrm{~m}, 2 \mathrm{H})$, $1.98-1.94(\mathrm{~m}, 1 \mathrm{H}) 1.73$ (br s, 3H), 1.68 (br s, 3H), 1.34-1.16 (m, 6H), 1.01 (d, 3H, J=6.1 Hz), 0.99 $(\mathrm{m}, 1 \mathrm{H}) ;{ }^{13} \mathrm{C} \mathrm{NMR}\left(\mathrm{CDCl}_{3}, 150 \mathrm{MHz}\right) \delta 154.6,148.6,140.9,136.4,135.3,130.6,129.6,128.7,128.3$, 
$60.5,44.2,40.0,37.3,36.8,36.4,33.7,31.5,28.6,27.3,25.4,23.8,19.9,17.5,12.3$; APCIMS $m / z 386$ $[\mathrm{M}+\mathrm{H}]^{+}$; HRMS-ES $m / z[\mathrm{M}+\mathrm{Na}]^{+} 408.2505$ (calcd for $\mathrm{C}_{24} \mathrm{H}_{35} \mathrm{NO}_{3} \mathrm{Na}, 408.2509$ ).

\subsubsection{Prenylation of 2,6-Dimethoxyphenol: Synthesis of $14,15 \& 16$}

A solution of 2-methyl-3-buten-2-ol $(640 \mathrm{mg}, 7.4 \mathrm{mmol})$ in DCM (3 mL) was added dropwise to a stirred mixture of 2,6-dimethoxyphenol $(\mathbf{1 3}, 612 \mathrm{mg}, 3.97 \mathrm{mmol})$ and $\mathrm{TsOH}(19 \mathrm{mg}$, cat) in $\mathrm{DCM} / \mathrm{MeOH}(3: 1,30 \mathrm{~mL})$. After stirring for $96 \mathrm{~h}$ at room temperature the solution was refluxed for $20 \mathrm{~h}$ and then partitioned between $\mathrm{H}_{2} \mathrm{O}$ and EtOAc. The organic phase was subjected to the standard work up procedure to yield a crude oil $(793 \mathrm{mg})$ which was subjected to flash chromatography $\left(\mathrm{C} 18, \mathrm{H}_{2} \mathrm{O} \rightarrow \mathrm{MeOH}\right.$ gradient) to yield the mono-prenylated product (14, $239 \mathrm{mg}, 1.08 \mathrm{mmol}, 27 \%$ ), the di-prenylated product $(\mathbf{1 5}, 96 \mathrm{mg}, 0.33 \mathrm{mmol}, 8 \%)$, and the triprenylated product $(\mathbf{1 6}, 20 \mathrm{mg}$, $0.055 \mathrm{mmol}, 1.4 \%$ ) along with recovered starting material (321 mg, 52\%).

2,6-Dimethoxy-3-(3-methylbut-2-enyl)phenol (14): oil; IR $v_{\max }$ 3456, 2931, 2835, 1493, 1288, 1090 $\mathrm{cm}^{-1} ;{ }^{1} \mathrm{H}$ NMR $\left(\mathrm{CDCl}_{3}, 600 \mathrm{MHz}\right) \delta 6.63(\mathrm{~d}, 1 \mathrm{H}, J=8.5 \mathrm{~Hz}), 6.60(\mathrm{~d}, 1 \mathrm{H}, J=8.4 \mathrm{~Hz}), 5.53$ (s, 1H, OH), 5.27 (m, 1H, H-8), 3.863 (s, 3H, OMe), 3.861 (s, 3H, OMe), 3.30 (d, 2H, J=7.3 Hz); 1.73 (s, 6H, H-10 \& H-11); ${ }^{13} \mathrm{C}$ NMR $\left(\mathrm{CDCl}_{3}, 150 \mathrm{MHz}\right) \delta 145.9,145.2,138.5,132.0,127.8,123.1$, 119.1, 106.4, 60.4, 56.2, 28.0, 25.7, 17.7; APCIMS $m / z 223[\mathrm{M}+\mathrm{H}]^{+}$; HRMS-ES $m / z[\mathrm{M}+\mathrm{Na}]^{+}$ 245.1142 (calcd for $\mathrm{C}_{13} \mathrm{H}_{18} \mathrm{O}_{3} \mathrm{Na}, 245.1148$ ).

2,6-Dimethoxy-3,4-bis(3-methylbut-2-enyl)phenol (15): pale yellow oil; IR $v_{\max } 3440,2964,2912$, 1854, 1497, 1309, $1116 \mathrm{~cm}^{-1} ;{ }^{1} \mathrm{H}$ NMR $\left(\mathrm{CDCl}_{3}, 600 \mathrm{MHz}\right) \delta 6.50(\mathrm{~s}, 1 \mathrm{H}, \mathrm{H}-5), 5.23$ (m, 1H, olefinic), 5.07 (m, 1H, olefinic), 3.85 (s, 3H, OMe), $3.83(\mathrm{~s}, 3 \mathrm{H}, \mathrm{OMe}), 3.32(\mathrm{~d}, 2 \mathrm{H}, J=6.5 \mathrm{~Hz}), 3.25(\mathrm{~d}, 2 \mathrm{H}$, $J=6.5 \mathrm{~Hz}), 1.77(\mathrm{~s}, 3 \mathrm{H}), 1.75(\mathrm{~s}, 3 \mathrm{H}), 1.71(\mathrm{~s}, 3 \mathrm{H}), 1.68(\mathrm{~s}, 3 \mathrm{H}) .{ }^{13} \mathrm{C} \mathrm{NMR}\left(\mathrm{CDCl}_{3}, 150 \mathrm{MHz}\right)$ $\delta 145.5,145.4,136.7,132.1,131.0(2 \times \mathrm{C}), 126.0,123.7,123.4,107.6,60.6,56.1,31.4,25.7,25.6$, 25.1, 17.9, 17.8; APCIMS $m / z 291[\mathrm{M}+\mathrm{H}]^{+}$; HRMS-ES $m / z[\mathrm{M}+\mathrm{Na}]^{+} 313.1763$ (calcd for $\left.\mathrm{C}_{18} \mathrm{H}_{26} \mathrm{O}_{3} \mathrm{Na}, 313.1774\right)$.

2,6-Dimethoxy-3,4,5-tris(3-methylbut-2-enyl)phenol (16): colorless oil; IR $v_{\max } 3400,2964,2912$, 2855, 1456, $1087 \mathrm{~cm}^{-1}$; ${ }^{1} \mathrm{H} \mathrm{NMR}\left(\mathrm{CDCl}_{3}, 600 \mathrm{MHz}\right) \delta 5.49$ (s, 1H, OH), 5.09 (m, 2H, olefinic), 4.97 (m, 1H, olefinic), 3.80 (s, 6H, OMe), 3.32 (d, 4H, $J=6.5 \mathrm{~Hz}$ ), 3.23 (d, 2H, $J=6.0 \mathrm{~Hz}), 1.74(\mathrm{~s}, 6 \mathrm{H}), 1.68$ (broad overlapping singlets, $12 \mathrm{H}) .{ }^{13} \mathrm{C} \mathrm{NMR}\left(\mathrm{CDCl}_{3}, 150 \mathrm{MHz}\right) \delta 144.2,140.1,131.2,131.0,130.7$, $129.5,123.9,123.8,60.9,27.8(2 \times \mathrm{C}), 25.6,25.55,25.53,17.90,17.91$; APCIMS $m / z 359[\mathrm{M}+\mathrm{H}]^{+}$; HRMS-ES $m / z[\mathrm{M}+\mathrm{Na}]^{+} 381.2409$ (calcd for $\mathrm{C}_{23} \mathrm{H}_{34} \mathrm{O}_{3} \mathrm{Na}, 381.2400$ ).

\subsubsection{Synthesis of the Glycosyl Donor 2,3,4,6-Tetra- $O$-benzoyl- $\beta$-D-galactopyranosyl}

Trichloroacetimidate (21)

The glycosyl donor was synthesized from 2,3,4,6-tetra- $O$-benzoyl- $\alpha$-D-galactopyranosyl bromide, which was freshly prepared using a previously described method [28]. The glycosyl bromide (2.05 g, $3.11 \mathrm{mmol}$ ) was hydrolyzed and subsequently reacted with trichloroacetonitrile according to existing methodology to provide the glycosyl donor 21 (704 mg, $0.951 \mathrm{mmol}, 31 \%$ over two steps) [29]. 
3.2.10. Synthesis of 2,6-Dimethoxyphenol-2,3,4,6-tetra- $O$-benzoyl- $\beta$-D-galactopyranoside (17)

2,6-Dimethoxyphenol $(\mathbf{1 3}, 30.0 \mathrm{mg}, 0.195 \mathrm{mmol})$ and freshly prepared benzoylated glycosyl donor (21, $151.0 \mathrm{mg}, 0.229 \mathrm{mmol})$ were dissolved in $8 \mathrm{~mL}$ anhydrous DCM and stirred with $3 \AA$ molecular sieves $\left(500 \mathrm{mg}\right.$ ) under a $\mathrm{N}_{2}$ atmosphere for $20 \mathrm{~min}$. Afterwards, the mixture was cooled to $-78{ }^{\circ} \mathrm{C}$ and $\mathrm{BF}_{3} \cdot \mathrm{Et}_{2} \mathrm{O}(0.206 \mathrm{mmol})$ was added. After stirring for $2.5 \mathrm{~h}$ at $-78{ }^{\circ} \mathrm{C}$, the glycosyl donor was completely consumed as indicated by TLC. The reaction was quenched with $\mathrm{Et}_{3} \mathrm{~N}(100 \mu \mathrm{L}$, excess), filtered, diluted with EtOAc, and partitioned with $\mathrm{H}_{2} \mathrm{O}$. The EtOAc phase was recovered and concentrated in vacuo to provide the crude galactoside. Purification by flash chromatography (silica, hexane $\rightarrow$ MTBE gradient), yielded 17 (101.9 mg, 0.139 mmoles, 71\%).

17: white solid; $[\alpha]^{25}+67.4\left(c 0.1917, \mathrm{CH}_{2} \mathrm{Cl}_{2}\right)$; IR $v_{\max } 3065,2962,2939,2838,1726,1601,1479$, 1258, 1109, 1069, $709 \mathrm{~cm}^{-1} ;{ }^{1} \mathrm{H}$ NMR $\left(\mathrm{C}_{6} \mathrm{D}_{6}, 600 \mathrm{MHz}\right) \delta 8.11(\mathrm{~d}, 2 \mathrm{H}, J=7.8 \mathrm{~Hz}), 8.10(\mathrm{~d}, 2 \mathrm{H}$, $J=7.8 \mathrm{~Hz}), 8.07(\mathrm{~d}, 2 \mathrm{H}, J=7.8 \mathrm{~Hz}), 8.00(\mathrm{~d}, 2 \mathrm{H}, J=7.8 \mathrm{~Hz}), 7.10(\mathrm{t}, 1 \mathrm{H}, J=7.5 \mathrm{~Hz}), 7.06(\mathrm{t}, 1 \mathrm{H}$, $J=7.5 \mathrm{~Hz}), 7.03(\mathrm{t}, 2 \mathrm{H}, J=7.7 \mathrm{~Hz}), 7.01(\mathrm{t}, 1 \mathrm{H}, J=7.5 \mathrm{~Hz}), 6.92(\mathrm{t}, 2 \mathrm{H}, J=7.6 \mathrm{~Hz}), 6.91(\mathrm{t}, 2 \mathrm{H}$, $J=7.6 \mathrm{~Hz}), 6.85(\mathrm{t}, 1 \mathrm{H}, J=7.5 \mathrm{~Hz}), 6.78(\mathrm{t}, 1 \mathrm{H}, J=8.4 \mathrm{~Hz}, \mathrm{H}-4), 6.73(\mathrm{t}, 2 \mathrm{H}, J=7.7 \mathrm{~Hz}), 6.60(\mathrm{dd}$, $\left.1 \mathrm{H}, J=10.4,7.9 \mathrm{~Hz}, \mathrm{H}-2^{\prime}\right), 6.23$ (d, 2H, $\left.J=8.4 \mathrm{~Hz}, \mathrm{H}-3\right), 6.14$ (dd, $\left.1 \mathrm{H}, J=3.6,1.2 \mathrm{~Hz}, \mathrm{H}-4^{\prime}\right), 5.80$ (dd, $\left.1 \mathrm{H}, J=10.4,3.6 \mathrm{~Hz}, \mathrm{H}-3^{\prime}\right), 5.44$ (d, 1H, $\left.J=7.9 \mathrm{~Hz}, \mathrm{H}-1^{\prime}\right), 4.67$ (dd, $\left.1 \mathrm{H}, J=11.3,6.6 \mathrm{~Hz}, \mathrm{H}-6^{\prime}\right), 4.36$ (dd, $1 \mathrm{H}, J=11.3,6.6 \mathrm{~Hz}, \mathrm{H}-6^{\prime}$ ), 3.66 (app. ddd, 1H, $J=6.6,1.2 \mathrm{~Hz}, \mathrm{H}-55^{\prime}$ ), 3.25 (s, 6H, OMe); ${ }^{13} \mathrm{C}$ NMR $\left(\mathrm{C}_{6} \mathrm{D}_{6}, 150 \mathrm{MHz}\right) \delta 165.9,165.8,165.7,165.4,153.9$ (C-2), 136.1 (C-1), 133.2, 133.1, 133.0, 132.7, 130.8, 130.5, 130.3, 130.1, 130.1, 130.0, 129.7, 129.6, 128.8, 128.6, 128.4, 128.3, 124.6 (C-4), 106.1 (C-3), 103.1 (C-1'), 72.7 (C-3'), 71.9 (C-5'), $71.4\left(\mathrm{C}-2^{\prime}\right), 68.8$ (C-4'), 62.3 (C-6'), 55.9 (OMe); HRMS-ES $m / z[\mathrm{M}+\mathrm{Na}]^{+} 755.2088$ (calcd for $\mathrm{C}_{42} \mathrm{H}_{36} \mathrm{O}_{12} \mathrm{Na}, 755.2099$ ).

3.2.11. Synthesis of 2,6-Dimethoxyphenol- $\beta$-D-galactopyranoside (18)

Compound 17 (40.3 mg, $55.0 \mu \mathrm{mol})$ was stirred with $\mathrm{K}_{2} \mathrm{CO}_{3}(38.8 \mathrm{mg})$ in $3 \mathrm{~mL} \mathrm{MeOH}$ :MTBE (5:1) for $20 \mathrm{~h}$. After deprotection was completed, as indicated by TLC (silica, hexane/MTBE), the reaction mixture was diluted with $\mathrm{H}_{2} \mathrm{O}$ and desalted by solid phase extraction $\left(\mathrm{C} 18,1: 19 \mathrm{MeOH}: \mathrm{H}_{2} \mathrm{O}\right)$. The product was eluted with $\mathrm{MeOH}$ and purified by flash chromatography $\left(\mathrm{C} 18, \mathrm{H}_{2} \mathrm{O} \rightarrow \mathrm{MeOH}\right.$ gradient $)$ to provide 18 (12.5 mg, $39.5 \mu \mathrm{mol}, 72 \%)$.

18: colorless solid; $[\alpha]^{25}-15.9\left(c 0.8333, \mathrm{CH}_{2} \mathrm{Cl}_{2}\right)$; IR $v_{\max } 3388,3008,2940,2841,1599,1480$, 1256, 1108, $1072 \mathrm{~cm}^{-1}$; ${ }^{1} \mathrm{H}$ NMR $\left(\left(\mathrm{CD}_{3}\right)_{2} \mathrm{SO}, 600 \mathrm{MHz}\right) \delta 6.97(\mathrm{t}, 1 \mathrm{H}, J=8.4 \mathrm{~Hz}, \mathrm{H}-4), 6.66(\mathrm{~d}, 2 \mathrm{H}$, $J=8.4 \mathrm{~Hz}, \mathrm{H}-3), 4.83$ (d, 1H, $\left.J=7.6 \mathrm{~Hz}, \mathrm{H}-1^{\prime}\right), 4.79-4.74$ (m, 2H, C-2'/3'-OH), 4.50-4.44 (m, 2H, C-4'/6'-OH), 3.74 (s, 6H, OMe), 3.67 (app. t, 1H, $J=3.3 \mathrm{~Hz}, \mathrm{H}-4^{\prime}$ ), 3.56-3.52 (m, 1H, H-2'), 3.56-3.52 (m, 1H, H-6'), 3.37-3.33 (m, 1H, H-3'), 3.36-3.32 (m, 1H, H-6'), 3.27 (app. t, 1H, $J=6.3 \mathrm{~Hz}$, $\left.\mathrm{H}-5^{\prime}\right) ;{ }^{13} \mathrm{C}$ NMR $\left(\left(\mathrm{CD}_{3}\right)_{2} \mathrm{SO}, 150 \mathrm{MHz}\right) \delta 153.0(\mathrm{C}-2), 134.9(\mathrm{C}-1), 123.7(\mathrm{C}-4), 106.6(\mathrm{C}-3), 103.5$ $\left(\mathrm{C}-1^{\prime}\right), 75.5\left(\mathrm{C}-5^{\prime}\right), 73.2\left(\mathrm{C}-3^{\prime}\right), 71.4\left(\mathrm{C}-2^{\prime}\right), 67.9\left(\mathrm{C}-4^{\prime}\right), 60.1\left(\mathrm{C}-6^{\prime}\right), 56.4(\mathrm{OMe})$; HRMS-ES $m / z$ $[\mathrm{M}+\mathrm{Na}]^{+} 339.1043$ (calcd for $\mathrm{C}_{14} \mathrm{H}_{20} \mathrm{O}_{8} \mathrm{Na}, 339.1050$ ). 
3.2.12. Synthesis of 2,6-Dimethoxy-3-(3-methylbut-2-enyl)phenol-2,3,4,6-tetra- $O$-benzoyl- $\beta$-Dgalactopyranoside (19)

The glycosylation procedure, described for the synthesis of $\mathbf{1 7}$, was repeated using the benzoylated glycosyl donor $(\mathbf{2 1}, 175.6 \mathrm{mg}, 0.266 \mathrm{mmol})$ and $\mathbf{1 4}(44.6 \mathrm{mg}, 0.201 \mathrm{mmol})$ as the glycosyl accepting substrate. The reaction crude was separated by flash chromatography (silica, hexane $\rightarrow$ MTBE gradient) to provide 19 (149.1 $\mathrm{mg}, 0.186 \mathrm{mmol}, 93 \%)$.

19: pale yellow solid; $[\alpha]^{25}+75.9\left(c 0.225, \mathrm{CH}_{2} \mathrm{Cl}_{2}\right)$; IR $v_{\max } 3063,2966,2936,1726,1602,1493$, 1451, 1094, 1069, $709 \mathrm{~cm}^{-1}$; ${ }^{1} \mathrm{H}$ NMR $\left(\mathrm{CD}_{3} \mathrm{OD}, 600 \mathrm{MHz}\right) \delta 8.13(\mathrm{~d}, 2 \mathrm{H}, J=7.7 \mathrm{~Hz}), 7.90(\mathrm{~d}, 4 \mathrm{H}$, $J=7.8 \mathrm{~Hz}), 7.75(\mathrm{~d}, 2 \mathrm{H}, J=7.8 \mathrm{~Hz}), 7.67(\mathrm{t}, 1 \mathrm{H}, J=7.7 \mathrm{~Hz}), 7.57(\mathrm{t}, 1 \mathrm{H}, J=7.7 \mathrm{~Hz}), 7.54(\mathrm{t}, 2 \mathrm{H}$, $J=7.7 \mathrm{~Hz}), 7.51(\mathrm{t}, 1 \mathrm{H}, J=7.7 \mathrm{~Hz}), 7.45(\mathrm{t}, 1 \mathrm{H}, J=7.6 \mathrm{~Hz}), 7.40(\mathrm{t}, 2 \mathrm{H}, J=7.7 \mathrm{~Hz}), 7.36(\mathrm{t}, 2 \mathrm{H}$, $J=7.7 \mathrm{~Hz}), 7.25$ (t, 2H, $J=7.7 \mathrm{~Hz}), 6.80$ (d, 1H, $J=8.6 \mathrm{~Hz}, \mathrm{H}-4), 6.54$ (d, 1H, $J=8.6 \mathrm{~Hz}, \mathrm{H}-5), 6.03$ (dd, $1 \mathrm{H}, J=10.3,8.0 \mathrm{~Hz}, \mathrm{H}-2^{\prime}$ ), 6.00 (app. d, 1H, $J=3.4 \mathrm{~Hz}, \mathrm{H}-4^{\prime}$ ), 5.78 (dd, 1H, $J=10.3,3.4 \mathrm{~Hz}, \mathrm{H}-3^{\prime}$ ), 5.64 (d, 1H, $J=8.0 \mathrm{~Hz}, \mathrm{H}-1^{\prime}$ ), 5.14 (app. t, 1H, $\left.J=7.4 \mathrm{~Hz}, \mathrm{H}-8\right), 4.58$ (dd, 1H, $J=10.8,7.0 \mathrm{~Hz}, \mathrm{H}-6^{\prime}$ ), 4.54 (app. dd, 1H, $J=7.0,4.9 \mathrm{~Hz}, \mathrm{H}-5^{\prime}$ ), 4.47 (dd, 1H, $J=10.8,4.9 \mathrm{~Hz}, \mathrm{H}-6^{\prime}$ ), 3.75 (s, 3H, C2-OMe), 3.53 (s, 3H, C6-OMe), 3.17-3.09 (m, 2H, H-7), 1.67 (s, 3H, H-10), 1.64 (s, 3H, H-11); ${ }^{13} \mathrm{C}$ NMR $\left(\mathrm{CD}_{3} \mathrm{OD}, 150 \mathrm{MHz}\right) \delta 167.5,167.3,167.1,166.8,152.7$ (C-2), 152.6 (C-6), 139.9 (C-1), 134.9, 134.6, $134.5,134.4,134.3,132.9,131.0,131.0,130.9,130.7,130.7,130.6,130.6,130.5,130.2$ (C-9), 129.9, 129.6, 129.6, 129.5, 129.5, 129.1 (C-3), 129.0, 128.8, 128.7, 125.9 (C-4), 124.4 (C-8), 109.0 (C-5), $103.2\left(\mathrm{C}-1^{\prime}\right), 73.6\left(\mathrm{C}-3^{\prime}\right), 73.0\left(\mathrm{C}-5^{\prime}\right), 72.3$ (C-2'), 70.2 (C-4'), 63.7 (C-6'), 61.7 (2-OMe), 56.6 (6-OMe), 29.0 (C-7), 25.9 (C-10), 17.9 (C-11); HRMS-ES $m / z[\mathrm{M}+\mathrm{Na}]^{+} 823.2754$ (calcd for $\left.\mathrm{C}_{47} \mathrm{H}_{44} \mathrm{O}_{12} \mathrm{Na}, 823.2725\right)$.

3.2.13. Synthesis of 2,6-Dimethoxy-3-(3-methylbut-2-enyl)phenol- $\beta$-D-galactopyranoside (20)

The deprotection procedure, described for the synthesis of 18, was repeated with 19 (38.5 $\mathrm{mg}$, $48.1 \mu \mathrm{mol})$ and $\mathrm{K}_{2} \mathrm{CO}_{3}(33.4 \mathrm{mg})$. The deprotected glycoside was purified with the method described for 17 to yield 20 (13.9 mg, $36.2 \mu \mathrm{mol}, 75 \%)$.

20: colorless solid; $[\alpha]^{25}{ }_{\mathrm{D}}-6.44\left(c 0.6917, \mathrm{CH}_{3} \mathrm{OH}\right)$; IR $v_{\max } 3392,2967,2914,1602,1494,1463$, 1442, $1090 \mathrm{~cm}^{-1}$; ${ }^{1} \mathrm{H}$ NMR $\left(\left(\mathrm{CD}_{3}\right)_{2} \mathrm{SO}, 600 \mathrm{MHz}\right) \delta 6.79(\mathrm{~d}, 1 \mathrm{H}, J=8.5 \mathrm{~Hz}, \mathrm{H}-4), 6.70(\mathrm{~d}, 1 \mathrm{H}$, $J=8.5 \mathrm{~Hz}, \mathrm{H}-5), 5.20$ (app. t, $1 \mathrm{H}, J=7.3 \mathrm{~Hz}, \mathrm{H}-8), 4.96$ (d, 1H, $\left.J=4.5 \mathrm{~Hz}, \mathrm{C}-2^{\prime}-\mathrm{OH}\right), 4.92$ (d, 1H, $\left.J=7.6 \mathrm{~Hz}, \mathrm{H}-1^{\prime}\right), 4.80$ (d, 1H, $\left.J=5.3 \mathrm{~Hz}, \mathrm{C}-3^{\prime}-\mathrm{OH}\right), 4.49$ (m, 1H, C-4'-OH), 4.47 (m, 1H, C-6'-OH), 3.76 (s, 3H, C6-OMe), 3.72 (s, 3H, C2-OMe), 3.68 (app. dd, 1H, $J=3.5$ Hz, H-4'), 3.59-3.55 (m, 1H, H-2'), 3.55-3.52 (m, 1H, H-6'), 3.39-3.36 (m, 1H, H-3'), 3.35-3.32 (m, 2H, H-6'), 3.29 (app. t, 1H, $\left.J=6.2 \mathrm{~Hz}, \mathrm{H}-5^{\prime}\right), 3.24-3.15(\mathrm{~m}, 2 \mathrm{H}, \mathrm{H}-7), 1.68(\mathrm{~s}, 3 \mathrm{H}, \mathrm{H}-10), 1.67$ (s, 3H, H-11); ${ }^{13} \mathrm{C}$ NMR $\left(\left(\mathrm{CD}_{3}\right)_{2} \mathrm{SO}, 150 \mathrm{MHz}\right) \delta 151.6(\mathrm{C}-2), 151.1$ (C-6), 138.8 (C-1), 131.3 (C-9), 127.4 (C-3), 123.6 (C-4), 123.4 (C-8), 108.9 (C-5), 103.2 (C-1'), 75.5 (C-5'), 73.2 (C-3'), 71.4 (C-2'), 67.9 (C-4'), 60.7 (6-OMe), 60.1 (C-6'), 56.5 (2-OMe), 27.7 (C-7), 25.5 (C-10), 17.6 (C-11); HRMS-ES $m / z\left[\mathrm{M}+\mathrm{Na}^{+} 407.1687\right.$ (calcd for $\mathrm{C}_{19} \mathrm{H}_{28} \mathrm{O}_{8} \mathrm{Na}, 407.1676$ ). 


\section{Conclusions}

In conclusion, we have synthesized a series of pseudopterosin and pseudopteroxazole derivatives, including simple prenylated aromatic diterpene mimics, and evaluated their antimicrobial activity against $M$. tuberculosis $\mathrm{H}_{37} \mathrm{Rv}, M$. smegmatis, M. diernhoferi, MRSA and VRE. The major SAR emanating from this study pertains to the C-9 and C-10 substituents off the natural pseudopterosin-like scaffold. Variability in this region is tolerated for activity against $M$. tuberculosis $\mathrm{H}_{37} \mathrm{Rv}$ and other Gram-positive pathogens, such as MRSA and VRE. For instance, the phenolic (e.g., 9), benzoxazole (e.g., 7a), and quinoxaline (e.g., 5) derivatives all retained activity, though the latter was inactive against MRSA and VRE. Appropriate substitution at the C-9/C-10 position can lead to improved activity. In terms of Vero cell activity, while pseudopterosins (3a-d) did not display toxicity, a priori pseudopteroxazoles or other non-phenolic derivatives may represent better candidates for development since pseudopterosins may potentially be metabolized to the reactive ortho-quinone (4) or related derivatives.

It is likely that pseudopterosins and pseudopteroxazoles operate through a similar, and potentially novel, mechanism of action. We have commenced studies aiming to identify the antimicrobial mechanism of action of the pseudopteroxazoles and have begun investigating the effect of modifying other regions of the scaffold on biological activity.

\section{Acknowledgments}

The authors are grateful for services provided by S. Franzblau and colleagues at the Institute for Tuberculosis Research (U Illinois), who conducted the LORA, MABA and Vero cell assays on a fee for service basis. We also acknowledge experimental assistance from M. Lanteigne (microbiology) and K. Ballem (synthesis), and for NMR services provided by L. Kerry and C. Kirby (Agriculture \& Agrifood Canada). The authors gratefully acknowledge financial support from the Natural Sciences and Engineering Council of Canada (NSERC), the Canada Research Chair Program, the Atlantic Innovation Fund, and the Jeanne and Jean-Louis Levesque Foundation to UPEI; and Nautilus acknowledges funding from the National Research Council's Industrial Research Assistance Program (IRAP). We are indebted to the Government of The Bahamas for providing a Marine Resource Collections Permit.

\section{References and Notes}

1. Stop TB Partnership. The Global Plan to Stop TB 2011-2015: Transforming the Fight towards Elimination of Tuberculosis; World Health Organization: Geneva, Switzerland, 2011.

2. Kaneko, T.; Cooper, C.; Mdluli, K. Challenges and opportunities in developing novel drugs for TB. Future Med. Chem. 2011, 3, 1373-1400.

3. Koul, A.; Arnoult, E.; Lounis, N.; Guillemont, J.; Andries, K. The Challenge of new drug discovery for tuberculosis. Nature 2011, 469, 483-490.

4. Dover, L.G.; Coxon, G.D. Current status and research strategies in tuberculosis drug development. J. Med. Chem. 2011, 54, 6157-6165. 
5. Newman, D.J.; Cragg, G.M. Natural product scaffolds as leads to drugs. Future Med. Chem. 2009, 1, 1415-1427.

6. Rodriguez, A.D.; Ramirez, C.; Rodriguez, I.I.; Gonzalez, E. Novel antimycobacterial benzoxazole alkaloids, from the west Indian Sea whip Pseudopterogorgia elisabethae. Org. Lett. 1999, 1, 527-530.

7. Rodriguez, I.I.; Rodriguez, A.D. Homopseudopteroxazole, a new antimycobacterial diterpene alkaloid from Pseudopterogorgia elisabethae. J. Nat. Prod. 2003, 66, 855-857.

8. Harmata, M.; Hong, X. Benzothiazines in synthesis. A total synthesis of pseudopteroxazole. Org. Lett. 2005, 7, 3581-3583.

9. Harmata, M.; Cai, Z.; Chen, Y. Benzothiazines in synthesis. A formal total synthesis of pseudopteroxazole. J. Org. Chem. 2009, 74, 5559-5561.

10. Davidson, J.P.; Corey, E.J. First enantiospecific total synthesis of the antitubercular marine natural product pseudopteroxazole. Revision of assigned stereochemistry. J. Am. Chem. Soc. 2003, 125, 13486-13489.

11. McCulloch, M.W.; Berrue, F.; Haltli, B.; Kerr, R.G. One-pot syntheses of pseudopteroxazoles from pseudopterosins: A rapid route to non-natural congeners with improved antimicrobial activity. J. Nat. Prod. 2011, 74, 2250-2256.

12. More than 26 different pseudopterosins have been identified in nature, these can possess different configurations about the aglycone and/or different sugars.

13. Berrue, F.; McCulloch, M.W.B.; Kerr, R.G. Marine diterpene glycosides. Bioorg. Med. Chem. 2011, 19, 6702-6719.

14. Look, S.A.; Fenical, W.; Jacobs, R.S.; Clardy, J. The pseudopterosins: Anti-inflammatory and analgesic natural products from the sea whip Pseudopterogorgia elisabethae. Proc. Natl. Acad. Sci. USA 1986, 83, 6238-6240.

15. Rodriguez, I.I.; Shi, Y.P.; Garcia, O.J.; Rodriguez, A.D.; Mayer, A.M.; Sanchez, J.A.; Ortega-Barria, E.; Gonzalez, J. New pseudopterosin and seco-pseudopterosin diterpene glycosides from two Colombian isolates of Pseudopterogorgia elisabethae and their diverse biological activities. J. Nat. Prod. 2004, 67, 1672-1680.

16. Correa, H.; Aristizabal, F.; Duque, C.; Kerr, R. Cytotoxic and antimicrobial activity of pseudopterosins and seco-pseudopterosins isolated from the octocoral Pseudopterogorgia elisabethae of San Andres and Providencia Islands (Southwest Caribbean Sea). Mar. Drugs 2011, 9, 334-343.

17. Ata, A.; Win, H.Y.; Holt, D.; Holloway, P.; Segstro, E.P.; Jayatilake, G.S. New antibacterial diterpenes from Pseudopterogorgia elisabethae. Helv. Chim. Acta 2004, 87, 1090-1098.

18. Lazerwith, S.E.; Johnson, T.W.; Corey, E.J. Syntheses and stereochemical revision of pseudopterosin G-J aglycon and helioporin E. Org. Lett. 2000, 2, 2389-2392.

19. Roussis, V.; Wu, Z.; Fenical, W.; Strobel, S.A.; Van Duyne, G.D.; Clardy, J. New anti-inflammatory pseudopterosins from the marine octocoral Pseudopterogorgia elisabethae. J. Org. Chem. 1990, $55,4916-4922$.

20. Franzblau, S.G.; Witzig, R.S.; McLaughlin, J.C.; Torres, P.; Madico, G.; Hernandez, A.; Degnan, M.T.; Cook, M.B.; Quenzer, V.K.; Ferguson, R.M.; et al. Rapid, low-technology MIC determination with clinical Mycobacterium tuberculosis isolates by using the microplate Alamar Blue assay. J. Clin. Microbiol. 1998, 36, 362-366. 
21. Falzari, K.; Zhu, Z.; Pan, D.; Liu, H.; Hongmanee, P.; Franzblau, S.G. In vitro and in vivo activities of macrolide derivatives against Mycobacterium tuberculosis. Antimicrob. Agents Chemother. 2005, 49, 1447-1454.

22. Cho, S.H.; Warit, S.; Wan, B.; Hwang, C.H.; Pauli, G.F.; Franzblau, S.G. Low-oxygen-recovery assay for high-throughput screening of compounds against nonreplicating Mycobacterium tuberculosis. Antimicrob. Agents Chemother. 2007, 51, 1380-1385.

23. Collins, L.; Franzblau, S.G. Microplate alamar blue assay versus BACTEC 460 system for high-throughput screening of compounds against Mycobacterium tuberculosis and Mycobacterium avium. Antimicrob. Agents Chemother. 1997, 41, 1004-1009.

24. Molina-Salinas, G.M.; Rivas-Galindo, V.M.; Said-Fernandez, S.; Lankin, D.C.; Munoz, M.A.; Joseph-Nathan, P.; Pauli, G.F.; Waksman, N. Stereochemical analysis of leubethanol, an anti-TB-active serrulatane, from Leucophyllum frutescens. J. Nat. Prod. 2011, 74, 1842-1850.

25. Arbex, M.A.; Varella Mde, C.; Siqueira, H.R.; Mello, F.A. Antituberculosis drugs: Drug interactions, adverse effects, and use in special situations. Part 2: Second line drugs. J. Bras. Pneumol. 2010, 36, 641-656.

26. Shi, R.; Itagaki, N.; Sugawara, I. Overview of anti-tuberculosis (TB) drugs and their resistance mechanisms. Mini Rev. Med. Chem. 2007, 7, 1177-1185.

27. Altaf, M.; Miller, C.H.; Bellows, D.S.; O'Toole, R. Evaluation of the Mycobacterium smegmatis and BCG models for the discovery of Mycobacterium tuberculosis inhibitors. Tuberculosis (Edinb.) 2010, 90, 333-337.

28. Marchbank, D.H.; Kerr, R.G. Semisynthesis of fuscoside B analogues and eunicosides, and analysis of anti-inflammatory activity. Tetrahedron 2011, 67, 3053-3061.

29. Mbadugha, B.N.; Menger, F.M. Sugar/steroid/sugar conjugates: Sensitivity of lipid binding to sugar structure. Org. Lett. 2003, 5, 4041-4044.

Samples Availability: Available from the authors.

(C) 2012 by the authors; licensee MDPI, Basel, Switzerland. This article is an open access article distributed under the terms and conditions of the Creative Commons Attribution license (http://creativecommons.org/licenses/by/3.0/). 